\title{
Numerical Simulation Study on the Influence of Different Factors on the Uplift Bearing Capacity of Root Piles, Straight-Shaft Piles, and Pedestal Piles
}

\author{
Junpeng Zhou $\mathbb{D}^{1},{ }^{1}$ Jun Yuan $\mathbb{D}{ }^{2},{ }^{2}$ Xuefeng Huang $\mathbb{D}^{1},{ }^{1,3}$ and Xueming Wang $\mathbb{D}^{2}$ \\ ${ }^{1}$ Department of Military Installations, Army Logistical University of PLA, Chongqing 401311, China \\ ${ }^{2}$ Northwest Electric Power Design Institute Co., Ltd of China Power Engineering Consulting Group, Xi'an 710075, China \\ ${ }^{3}$ College of Hohai, Chongqing Jiaotong University, Chongqing 400074, China
}

Correspondence should be addressed to Xuefeng Huang; hxfen60@163.com

Received 19 August 2020; Revised 22 October 2020; Accepted 30 October 2020; Published 16 November 2020

Academic Editor: Song-He Wang

Copyright (C) 2020 Junpeng Zhou et al. This is an open access article distributed under the Creative Commons Attribution License, which permits unrestricted use, distribution, and reproduction in any medium, provided the original work is properly cited.

Root pile (hereafter called RP), which is a promising new type of noncircular cross-section-shaped pile and meets the requirements of the development of the uplift pile, was introduced for promotion. On the basis of validation of experimental and numerical results, finite element models were established to study the influence of the arrangement of roots and dimension parameters on the uplift bearing capacity and the economy of RP compared with that of the straight-shaft pile and pedestal pile (hereafter called SP and PP, respectively). The results show that the uplift bearing capacity of RP is higher than that of SP and PP, and the longer the pile length is, the more the bearing capacity of RP would increase compared with that of SP and PP. In order to further improve the bearing capacity of RP, the bearing mechanism of the root was analysed, and the suggested values of root size and spacing of layers are given. In addition, the most economical way to increase pile bearing capacity is to increase pile length rather than increasing pile diameter.

\section{Introduction}

With the development of infrastructure construction, the development of piles is exposed to a series of challenges, including higher bearing capacity and less material consumption. Piles with noncircular cross-section shape which are promising new pile types developed based on conventional SP meet the requirements of the development of pile foundation. There are several popular piles with noncircular cross-section shape in the last few years: squeezed branch piles [1, 2], PP [3-6], screw piles $[7,8], X$-shaped piles $[9,10]$, and so on, and PP was often adopted for buildings bearing uplift load.

$\mathrm{RP}$ is a new type of pile and put forward by Yin [11] firstly, as shown in Figure 1, which is formed by grafting prefabricated roots onto SP. The mechanism of RP is including side friction of the pile shaft and cantilever action of prefabricated roots, and RP therefore could improve bearing capacity effectively. In addition, compaction effect generated by pushing roots into the surrounding soil will enhance the physical and mechanical properties of the surrounding soil; however, root compaction effect is difficult to be taken into quantitative consideration in practical engineering.

The construction process of RP is relatively complicated, and the construction method varies according to the sequence of pushing roots and installation of reinforcement. Pushing roots firstly and installation of reinforcement later were adopted in the field testing, and the corresponding brief construction process is shown in Figure 2.

$\mathrm{RP}$ was mostly used as a compressive bearing foundation since its advent, and investigation and application on the uplift bearing behaviour of RP is rare so that its uplift bearing capacity was often ignored by researchers. The compressive bearing capacity of root caissons and the optimal distribution of roots were investigated by Gong et al. [12] through field loading tests and Yin et al. [13] through numerical simulation, respectively, and their research 


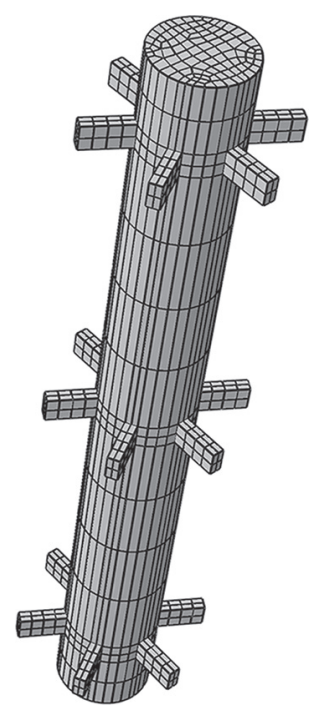

(a)

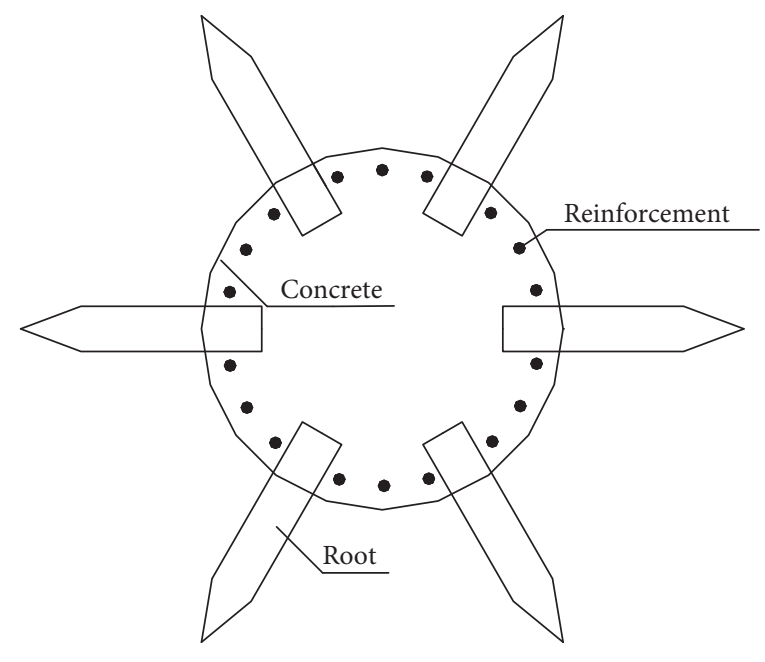

(b)

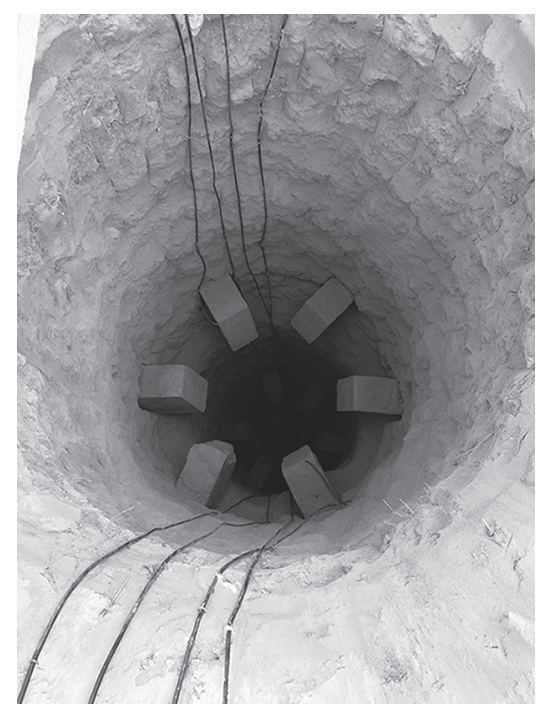

(c)

FIgURE 1: Diagram of RP. (a) Elevation of RP. (b) Layout of roots. (c) Site picture of roots after pushing.

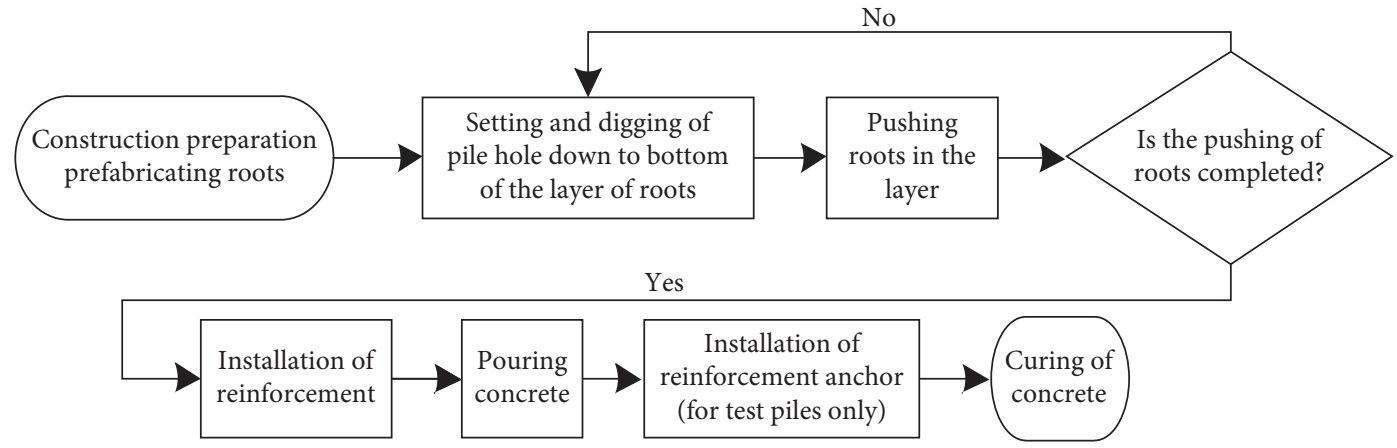

FIgURE 2: Construction process of RP.

studies both pointed out that the roots could significantly improve the compressive bearing capacity. Whether the existence of roots could improve the uplift bearing capacity is unknown, but it is worth to explore the influence of the arrangement of roots, pile length and diameter, and hollow sections on the uplift bearing capacity of RP and the advantages of RP compared with those of SP and PP.

On the basis of validation of experimental and numerical results, the above subjects were studied by numerical simulation. The bearing mechanism of the root was analysed, and the influence of the number and size of the root and the spacing of root layers on bearing capacity was discussed. Based on the analysis of the influence of pile length and diameter and hollow sections on the uplift bearing capacity of different pile types, the advantages of RP over PP were summarized. In addition, suggestions were put forward on how to increase the uplift bearing capacity.

\section{Materials and Methods}

2.1. Material. The soil was simulated by the Mohr-Coulomb model, and pile and roots both constructed by reinforced concrete were simulated by the elastic model. Material parameters are shown in Table 1, in which unit weight $\gamma$, Poisson's ratio $\nu$, cohesion $c$, and internal friction angle $\varphi$ were obtained by field tests and elastic modulus $E$ and dilation angle $\phi$ were obtained by calibration.

2.2. Constitutive Model. The Coulomb friction model was adopted to describe the friction behaviour between the contact surfaces. Since the holes of piles in the field tests were manually drilled and the side walls of the holes were relatively rough, the external friction angle $\delta$ between the soil and piles was chosen as $22^{\circ}$ which was the same as the soil internal friction angle $\varphi$, and the corresponding friction coefficient $\mu$ was 0.40 . The maximum side friction $\tau_{\max }$ was defined as follows:

$$
\tau_{\max }=\mu p_{n},
$$

where $p_{\mathrm{n}}$ is the normal pressure between the contact surfaces. In the Coulomb friction model of ABAQUS, the elastic slip distance $\Delta u_{\mathrm{el}, \text { slip }}$ should be specified. For small displacement not greater than $\Delta u_{\mathrm{el}, \text { slip }}$, a linear increase of the side friction until reaching to $\tau_{\max }$ is assumed, and for larger 
TABle 1: Model material parameters.

\begin{tabular}{|c|c|c|c|c|c|c|}
\hline Material & $\begin{array}{c}\text { Unit weight } \gamma \\
\left(\mathrm{kN} / \mathrm{m}^{3}\right)\end{array}$ & Elastic modulus $E(\mathrm{MPa})$ & Poisson's ratio $v$ & Cohesion $c(\mathrm{kPa})$ & Internal friction angle $\varphi\left({ }^{\circ}\right)$ & Dilation angle $\phi\left(^{\circ}\right)$ \\
\hline $\begin{array}{l}\text { Soil } \\
\end{array}$ & 16 & 15 & 0.3 & 20 & \multirow{2}{*}{22} & \multirow{2}{*}{2.2} \\
\hline Pile & 24.5 & 30000 & 0.2 & - & & \\
\hline
\end{tabular}

displacement, the side friction remains the same as $\tau_{\max }$. That is, the side friction conforms to the following relations:

$$
\left\{\begin{array}{l}
\tau=k_{\mathrm{s}} \Delta u\left(\Delta u \leq \Delta u_{\mathrm{el}, \mathrm{slip}}\right) \\
\tau=\tau_{\max }\left(\Delta u>\Delta u_{\mathrm{el}, \mathrm{slip}}\right)
\end{array}\right.
$$

where $k_{s}=\tau_{\max } / \Delta u_{\text {el,slip }}$ is the tangential stiffness of the contact surfaces. According to previous studies [14, 15], side friction would reach its maximum value $\tau_{\max }$ for a relative displacement of $5 \mathrm{~mm}$. The elastic slip distance $\Delta u_{\mathrm{el}, \mathrm{slip}}$ in the numerical model of this paper was therefore $5 \mathrm{~mm}$.

2.3. Numerical Simulation. The diameter and the buried depth of the model piles were $1.2-2.8 \mathrm{~m}$ and 5-25 $\mathrm{m}$. For all PP mentioned in this paper, the diameter of the enlarged base was 1.5 times the diameter of the pile shaft, and the height of the enlarged base was $1 \mathrm{~m}$. Roots $0.15-0.3 \mathrm{~m}$ in width and $0.3-0.4 \mathrm{~m}$ in height were extended $0.6-1.6 \mathrm{~m}$ out of the pile shaft and were arranged in the circular direction with equal spacing. It should be noted that the compaction effect of roots pushing into soil was not considered in the numerical simulation.

The radial and axial dimensions of the base were, respectively, 25 and 16.7 times the pile diameter, which was found from calculations sufficient to avoid a significant falsification of the calculation results. The displacement in $X$ and $Y$ horizontal directions of the lateral boundary and in all directions of the bottom boundary had been constrained. The piles and soil were discretized into C3D8R elements, and the $3 \mathrm{D}$ finite element mesh of the model is shown in Figure 3.

The models were calculated in three steps. Firstly, the balance of the geostress field was carried out. In this process, the soil weight was applied to the whole model, and the horizontal stress coefficient $k$ was defined. It is worth noting that the magnitude of $k$ determines the magnitude of side friction, namely, $k$ has a great influence on the numerical results. Kulhway and Kozera [16] pointed out that the value of $k$ was related to the safety level of buildings and the stress history of soil (the overconsolidation ratio of soil (OCR)), which could be taken between the active earth pressure coefficient $k_{\mathrm{a}}$ and the passive earth pressure coefficient $k_{\mathrm{p}}$. It was decided to adopt $k_{\mathrm{p}}=\tan ^{2}\left(45^{\circ}+(\varphi / 2)\right)=2.04$ as the horizontal stress coefficient, and in this case, the numerical results can be in agreement with the experimental results to the greatest extent. Subsequently, the difference between pile and soil weight was applied to the pile again. At the end of this step, due to the difference of weight, small displacement and stress would be generated, which would be taken as the initial condition for numerical calculation. Finally, uplift

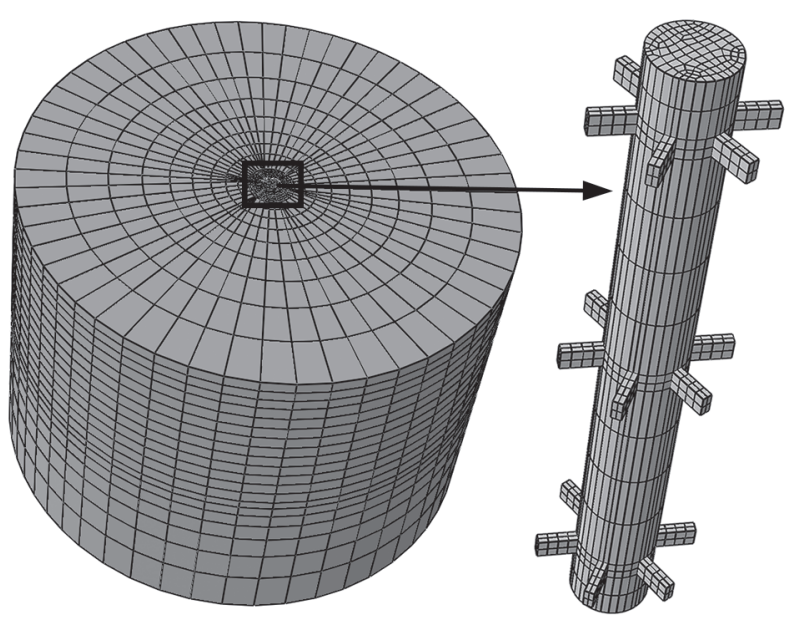

Figure 3: Finite element model.

load was applied to the pile top and increased gradually until the ultimate load was reached.

The load was loaded by force until the calculation did not converge. For the uplift piles, load displacement curves can be divided into mutational and varying gradually types, and the ultimate uplift bearing capacity can be taken as the prior load before mutation for the mutational curves and the load inducing upward displacement of $60 \mathrm{~mm}$ for varying gradually curves correspondingly.

\section{Validation of the Numerical Model}

Field loading tests were performed on three piles, including No. 1 SP, No. 2 PP, and No. 15 RP (see Table 2). The soil profile consisted of large thickness and continuous loess strata. Freeze-thaw could affect the strength of the loess $[17,18]$; however, the freeze-thaw is not involved in field tests; the purpose of the tests was to compare the bearing capacity of three pile types, so the effect of freeze-thaw on loess was not considered. Soil samples were collected and tested in a laboratory, and the properties of samples are shown in Table 1. All of the loading tests were conducted according to the slow loading method and loaded by hydraulic jacks in an increment of $300 \mathrm{kN}$, as shown in Figure 4. Displacement sensors were placed at the top of the pile head to measure uplift displacement. The comparison of experimental and numerical results of these three piles is shown in Figure 5.

It can be seen from Figure 5 that the uplift displacement obtained by the numerical simulation is larger than the experimental results, which is because the tangential stiffness of the contact surface remains unchanged at the elastic slip stage in the numerical simulation. However, for the field loading 
TABLE 2: Simulation programs and results of piles with different root arrangement.

\begin{tabular}{|c|c|c|c|c|c|c|c|}
\hline Pile No. & Pile type & Root No. per layer & $\begin{array}{l}\text { No. of } \\
\text { root layers }\end{array}$ & $\begin{array}{l}\text { Depth of the } \\
\text { first root layer }(d)\end{array}$ & $\begin{array}{c}\text { Spacing } \\
\text { between root layers }\end{array}$ & $\begin{array}{c}\text { Ultimate } \\
\text { bearing capacity } \\
Q_{\mathrm{u}}(\mathrm{kN})\end{array}$ & $\begin{array}{c}Q_{\mathrm{u}} \text { increment } \\
\text { compared with pile } \\
\text { No. } 1(\%)\end{array}$ \\
\hline 1 & \multirow{12}{*}{$\mathrm{RP}$} & & SP & & & \multicolumn{2}{|c|}{ Mutation, $32.13 \mathrm{~mm}, 2550 \mathrm{kN}$} \\
\hline 2 & & & $\mathrm{PP}$ & & & 3952 & 55.0 \\
\hline 3 & & 4 & 1 & 7.5 & & 3288 & 28.9 \\
\hline 4 & & 6 & 1 & 7.5 & & 3542 & 38.9 \\
\hline 5 & & 8 & 1 & 7.5 & & 3687 & 44.6 \\
\hline 6 & & 6 & 1 & 1 & \multicolumn{3}{|c|}{ Mutation, $31.74 \mathrm{~mm}, 2750 \mathrm{kN}, 7.6 \%$} \\
\hline 7 & & 6 & 1 & 2 & & \multicolumn{2}{|c|}{ Mutation, $34.68 \mathrm{~mm}, 3000 \mathrm{kN}, 17.6 \%$} \\
\hline 8 & & 6 & 1 & 3 & & \multicolumn{2}{|c|}{ Mutation, $39.94 \mathrm{~mm}, 3250 \mathrm{kN}, 27.5 \%$} \\
\hline 9 & & 6 & 1 & 4 & & 3512 & 37.7 \\
\hline 10 & & 6 & 1 & 5 & & 3597 & 41.1 \\
\hline 11 & & 6 & 2 & 4 & $1 \mathrm{~d}$ & 4079 & 60.0 \\
\hline 12 & & 6 & 2 & 4 & $2 \mathrm{~d}$ & 4250 & 66.7 \\
\hline 13 & 6 & 2 & 4 & $3 \mathrm{~d}$ & 4292 & 68.3 & \\
\hline 14 & 6 & 2 & 4 & $4 \mathrm{~d}$ & 4500 & 76.5 & \\
\hline 15 & 6 & 3 & 1 & $3 \mathrm{~d}$ & 4606 & 80.6 & \\
\hline
\end{tabular}

Note. $d$ which equals to $1.2 \mathrm{~m}$ is the diameter of the pile shaft. Pile No. 1,2 , and 15 are validation piles with the same size as the field testing piles. The length, width, and height of roots are $0.6,0.15$, and $0.3 \mathrm{~m}$, respectively.

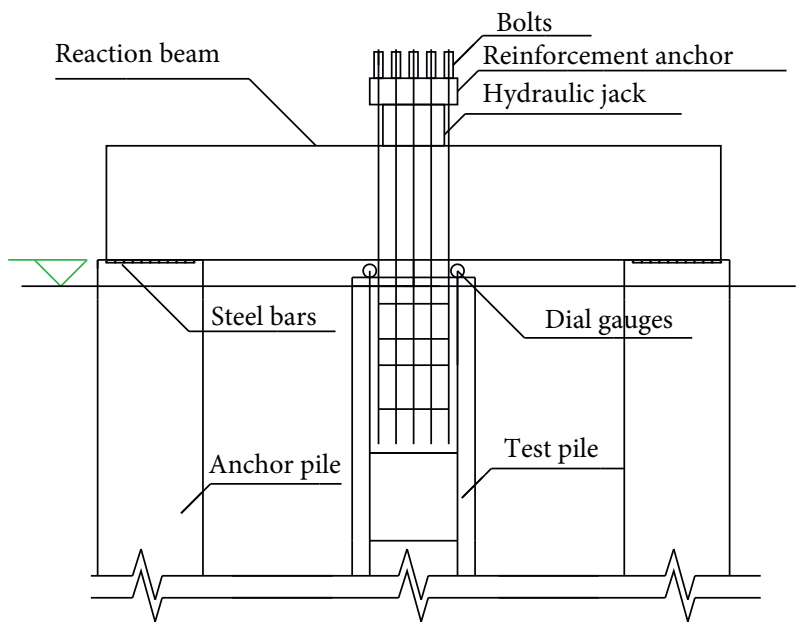

(a)

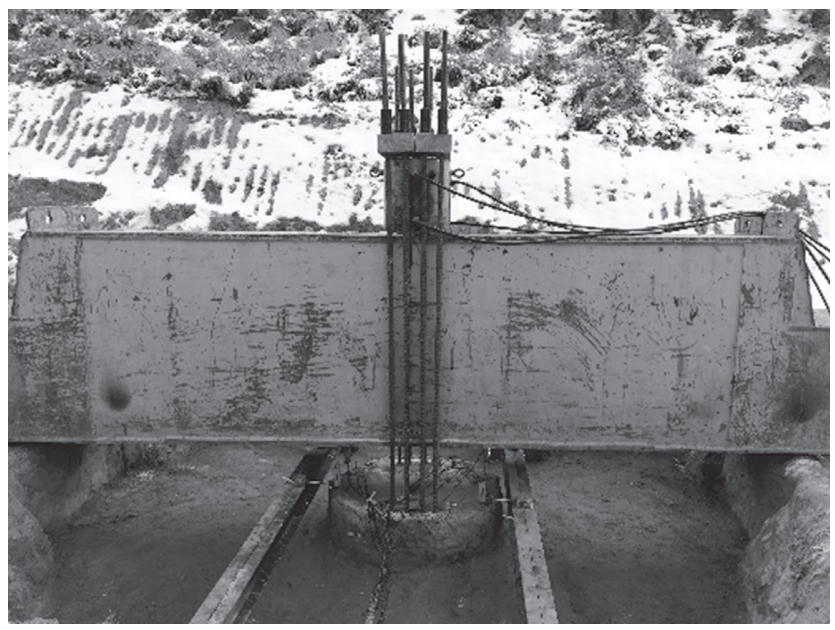

(b)

FIgURE 4: The layout of loading devices. (a) Schematic drawing of loading tests. (b) Field test diagram.

tests, the stiffness of the contact surface decayed gradually and then remained unchanged. The numerical results of the three testing piles were consistent with the trend of the experimental results in general, indicating that the numerical results could truly reflect the pile bearing capacity. And, then the numerical simulation studies of RP were carried out.

\section{Results and Discussion}

4.1. Study on Root Arrangement. In order to study the difference of bearing capacity of piles of different sections (including SP, PP, and RP) and the influence of the arrangement of roots on the uplift bearing capacity, numerical simulations were carried out. Specific simulation programs and the corresponding results are shown in Table 2, and the load displacement curves of pile No. 1-15 are shown in Figure 6.

\subsubsection{Root Pile with Single Root Layer}

(1) The Number of Roots. Figure 6 and Table 2 show that the ultimate uplift bearing capacity $Q_{\mathrm{u}}$ of RP and PP was significantly greater than that of SP, and the load displacement curves of pile No. 2-5 varied gradually, which was different from the mutation curve of SP and would provide a higher safety factor for the upper structure. Furthermore, the more the root grafting on the pile shaft, the higher the uplift bearing capacity; however, with the increase in the number of roots, the increase in $Q_{u}$ decreases gradually.

To further analyse the influence of the number of roots on $Q_{u}$, the plastic zone of soil around roots under $Q_{u}$ was extracted, as shown in Figure 7. For the RP No. 3 (as shown in Figure 7(a), the number of roots was 4, and the annular spacing of roots was $0.792 \mathrm{~m}$ ), the plastic zone of soil above the roots was concentrated around the roots and scattered, 


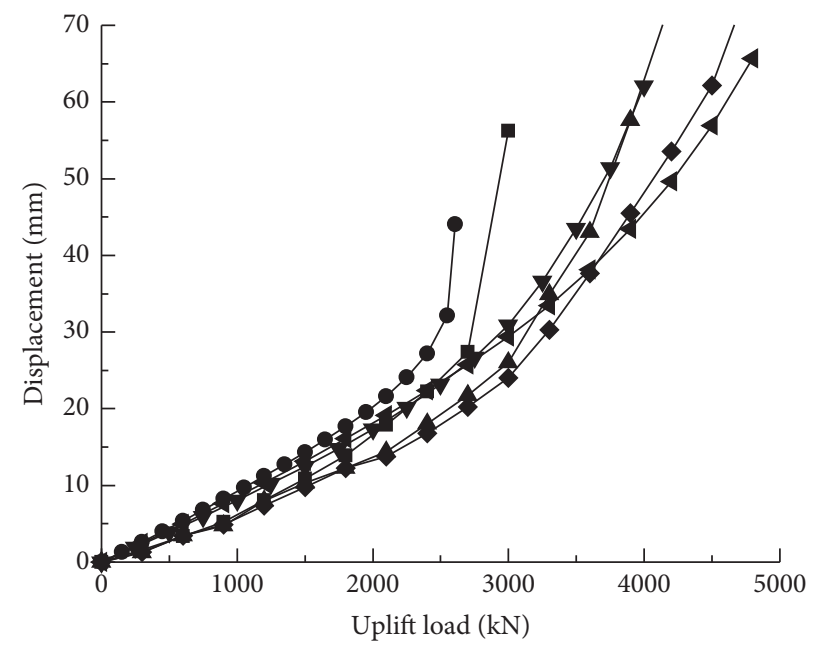

- Pile No.1 experiment result

$\rightarrow$ Pile No.1 numerical result

ــ Pile No.2 experiment result

$\neg$ Pile No.2 numerical result

$\checkmark$ Pile No.15 experiment result

— Pile No.15 numerical result

FIGURE 5: Comparison of experimental and numerical results.

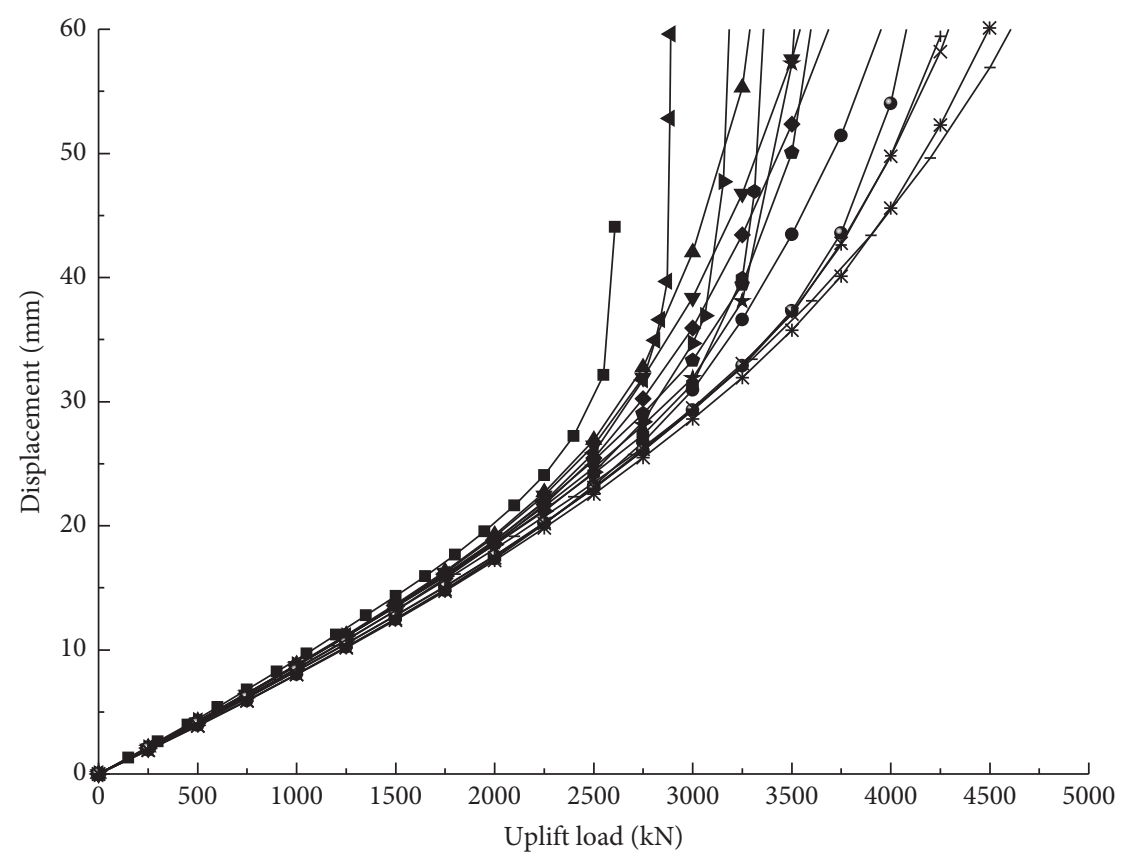

$\rightarrow$ No.1 straight-shaft pile

$\rightarrow$ No.2 pedestal pile

_- No.3 single layer with 4 roots

$\rightarrow$ No.4 single layer with 6 roots

$\longrightarrow$ No.5 single layer with 8 roots

$\longleftarrow$ No.6 single layer buried depth of $1 \mathrm{~d}$

$\rightarrow$ No.7 single layer buried depth of $2 \mathrm{~d}$

$\rightarrow$ No.8 single layer buried depth of $3 \mathrm{~d}$
* No.9 single layer buried depth of $4 \mathrm{~d}$

- No.10 single layer buried depth of $5 \mathrm{~d}$

$\rightarrow$ No.11 two layers with spacing of $1 \mathrm{~d}$

- N No.12 two layers with spacing of $2 \mathrm{~d}$

$*$ No.13 two layers with spacing of $3 \mathrm{~d}$

* No.14 two layers with spacing of $4 \mathrm{~d}$

_ No.15 three layers with spacing of $3 \mathrm{~d}$

Figure 6: Uplift load displacement of pile No. 1-15. 


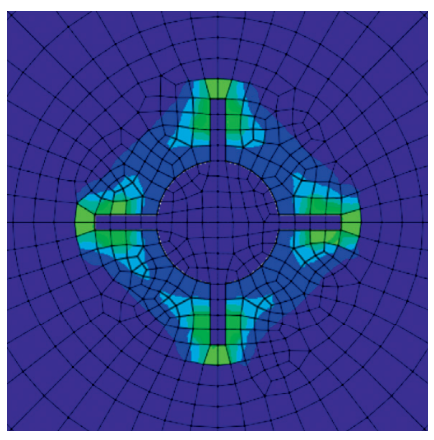

(a)

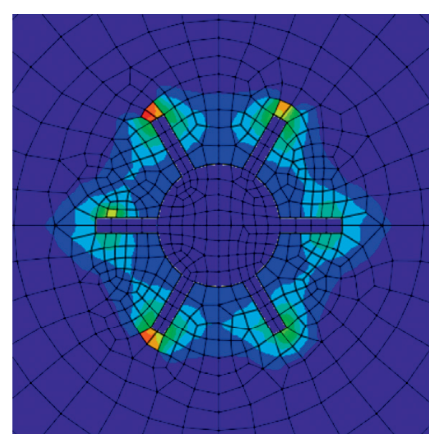

(b)

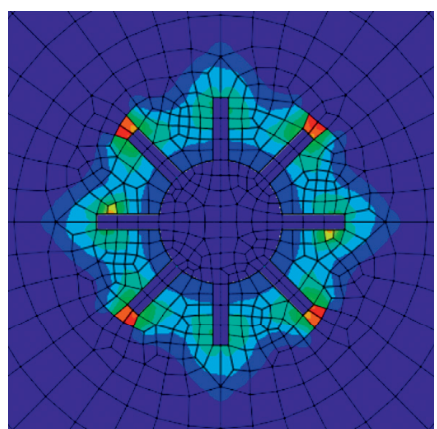

(c)

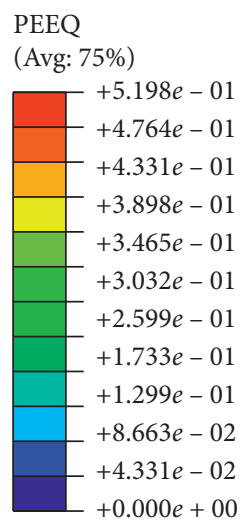

(d)

Figure 7: Plastic zone distribution of RP. (a) RP No. 3. (b) RP No. 4. (c) RP No. 5. (d) The legend. In Figure 7(d), PEEQ, which means equivalent plastic strain, is the cumulative result of plastic strain during the entire deformation process. The legend of Figures 10,11 , and 20 is the same as that of Figure $7(\mathrm{~d})$.

which would not fully mobilize the soil above the roots. On the contrary, the plastic zone of pile No. 5 (8 roots) was overlapped with each other, which would affect the effect of the root. As for RP No. 4, with 6 roots and $0.478 \mathrm{~m}$ annular spacing, because of the basically connected plastic zone, the soil above roots could be fully mobilized to resist the uplift load. Considering the influence of roots on $Q_{u}$ and the difficulty of construction and reinforcement, the number of roots should be 6 , and the annular spacing between roots should be $0.4-0.5 \mathrm{~m}$. Furthermore, the annular spacing between roots would be further analysed in Section 4.2.2.

(2) The Bearing Mechanism of Root. Taking RP No. 4 (6 roots) as an example, the effect and the bearing process of root were analysed. Figure 8 shows the axial stress distribution of the root, and Figure 9 shows the bending moments of the root along the cross section. It can be seen from the figures that, except for the region of the joint of roots and pile shaft, the distribution of axial stress and bending moment was close to the cantilever beam under uniform load. The size of uniform load was determined by magnitude of uplift load, physical and mechanical properties of the surrounding soil, and the spacing between roots. The roots bear uplift load independently while the spacing among them is large enough; however, the roots and the soil would work together, and the soil arch effect would come into play when the spacing is relatively small.

(3) The Buried Depth of Roots. As for RP No. 4 and 6-10, each pile has one root layer, and the roots' buried depth was $7.5,1$, $2,3,4$, and $5 \mathrm{~d}$, respectively. As seen from Figure 6 and Table 2, with the buried depth of roots changing from shallow to deep, load displacement curves gradually changed from sudden failure to slow destruction. Roots drive the soil to pull up together, which reduces the lateral pressure between base and pile shaft when the buried depth of roots was too shallow; for example, $Q_{\mathrm{u}}$ and load displacement curve of RP No. 6 (roots buried at $1 \mathrm{~d}$ depth) were similar to those of SP. In addition, the uplift displacement of RP No. 9 and 10

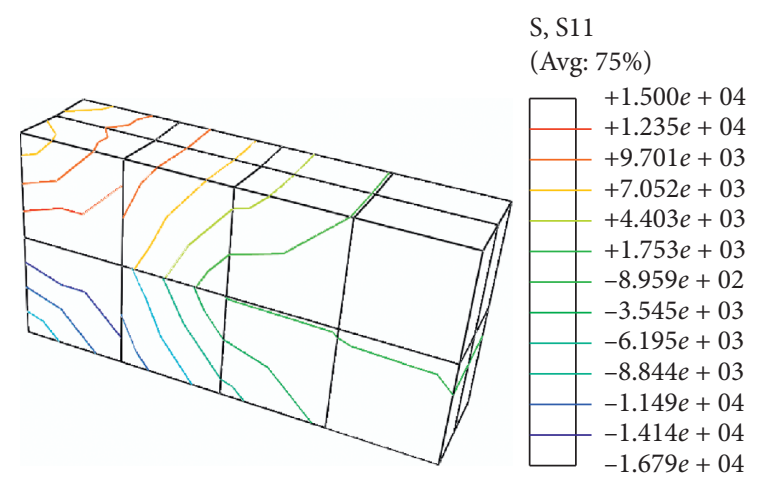

FIgURE 8: Axial stress distribution of the root. The unit of the legend is $\mathrm{kPa}$.

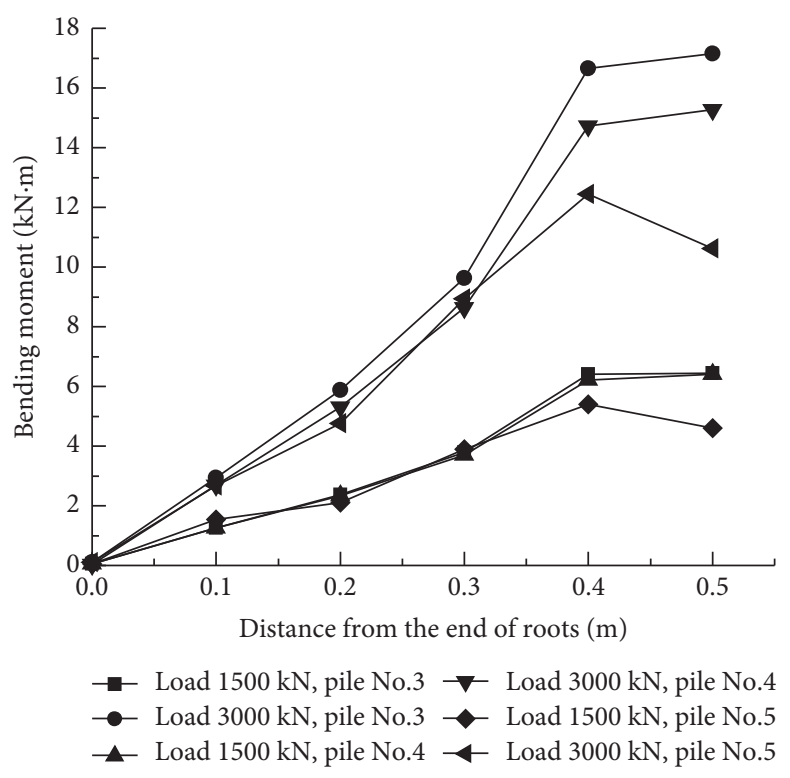

FIGURE 9: Bending moments of the root cross section. 
with the buried depth of $4 \mathrm{~d}$ and $5 \mathrm{~d}$ was smaller than that of No. 4 with the buried depth of $7.5 \mathrm{~d}$, i.e., a higher bearing capacity of pile No. 9 and 10; the reason of which was that the roots' buried depth of pile No. 4 was too large, and only when the uplift displacement was large enough, roots could come into full play. In conclusion, too shallow or too deep buried depth of roots was unfavourable to uplift bearing capacity, and the best embedding depth is between 4 and $5 \mathrm{~d}$.

As shown in Figure 10, when the depth of roots was shallower than $3 \mathrm{~d}$ (RP No. 6-8), the plastic zone would reach the ground under $Q_{u}$, and the reason of that uplift load displacement curves of pile No. 6-8 was mutation. When the buried depth was deeper than $4 \mathrm{~d}$ (RP No. 4, 9, and 10), the plastic zone showed a mountain-shaped distribution, which was concentrated in the range of $2 \mathrm{~d}$ above the roots.

4.1.2. The Spacing between Root Layers. As shown in Figure 6 and Table 2, the bearing capacity of one root layer RP was smaller than that of PP; however, with the increase in root layers, the uplift bearing capacity increases significantly, and the opposite relationship was shown. For the RP with 2 layers (No. 11-14), their bearing capacity increases with the increase in layer spacing. Because of shallow buried depth of the first root layer, $Q_{\mathrm{u}}$ of pile No. 15 with three root layers was only slightly larger than that of pile No. 14 .

Figure 11 shows the plastic zone distribution of RP No. 11-14 under $Q_{\mathrm{u}}$. Compared with Figure 10, it can be seen that the plastic zone of pile No. 11-14 was larger than that of piles with one root layer, which demonstrates that multilayer RP could mobilize soil to resist the uplift load in a larger range and lead to larger bearing capacity than one root layer RP. When the spacing was not more than $2 \mathrm{~d}$ (pile No. 11 and 12), the plastic zone between the two layers would be overlapped, which should be avoided. When the spacing was not less than $3 \mathrm{~d}$ (pile No. 13 and14), the plastic zone of the first and second layers would not be connected under $Q_{u}$, which indicates that the effect of two layers could be independently played and not be affected by each other. The study in Section 4.1.1 showed that the plastic zone was concentrated in the range of $2 \mathrm{~d}$ above the roots; in other words, when the spacing between two layers is not less than $2 \mathrm{~d}$, the influence between roots is small, which is the same conclusion as that in this section.

Through the above analysis, the relationship between the optimal buried depth of the first root layer and layer spacing and pile diameter $d$ ( $d$ was $1.2 \mathrm{~m}$ in this section) was discussed. In fact, these two values were totally unrelated to $d$, but are related to the actual distance, which will be further elaborated in Section 4.2.4.

\subsection{Study on the Influence of Pile Length and Diameter and Hollow Sections on Pile Bearing Capacity}

4.2.1. The Influence of Pile Length. Piles length ranging from $5 \mathrm{~m}$ to $25 \mathrm{~m}$ was simulated to compare the influence of pile length and type on the uplift bearing capacity. In addition, an RP length of $20 \mathrm{~m}$ with different number of root layers was analysed to study the influence of the root layout on the bearing capacity. Specific simulation programs and the corresponding results are shown in Table 3, and the load displacement curves of the piles are shown in Figure 12.

The bearing capacity of piles increases with the increase of pile length, and the load displacement curves of SP gradually changes from mutation to gradual variation. The $Q_{\mathrm{u}}$ increment of PP and RP compared with SP decreases with the increase in pile length, which is more obvious for PP. For example, load displacement curves of PP of length no less than $20 \mathrm{~m}$ are basically coincident with that of SP. The $Q_{\mathrm{u}}$ increment of RP was 15-25\% higher than that of PP. In addition, when pile length is large, roots arranged on the upper pile are available to bear the uplift load even when the uplift load is small; however, the enlarged base of PP could only bear load under the condition of the large displacement which would often exceed serviceability limit state. More importantly, the enlarged base of PP is difficult to operate, and collapse hole takes place frequently when the pile length is large; on the contrary, it is feasible to arrange several root layers on the upper part of the pile.

Figure 12 and Table 3 indicate that for RP No. 24-27 with 3-6 root layers, respectively, the bearing capacity increases with the increase in the number of root layers. Besides, the bearing capacity of pile No. 26 (5 root layers, and the maximum buried depth of roots is $15.6 \mathrm{~m}$ ) is almost the same as that of pile No. 27 (6 root layers), which means the effect of roots arranged on the lower part of the pile on the resistance of the uplift load is small especially for the long piles.

4.2.2. The Influence of Pile Diameter. Piles with a diameter of 1.6-2.8 $\mathrm{m}$ were simulated to compare the influence of pile diameter and the length and number of roots on the uplift bearing capacity. Specific simulation programs and the corresponding results are shown in Table 4, and the load displacement curves of the piles are shown in Figure 13.

Compared with SP, the $Q_{\mathrm{u}}$ increment of RP with different number and length of roots is shown in Figure 14. The bearing capacity of RP increases with the increase in the number and length of roots, while the increment rate decreases with the increase in the number of roots. In general, the bearing capacity of RP increases slightly with the increase in the number of roots when the annular spacing between the roots is smaller than $0.4-0.5 \mathrm{~m}$. The influence of root length on the bearing capacity is greater than root number, and it is suggested that the length of the root should not exceed 0.5 times the pile diameter due to the special construction process.

The height and width of the root should match the pile diameter; besides, the influence of the construction of the root on the reinforcement should also be taken into account. In other words, the width and the height of the root should not exceed the spacing between main reinforcement and the spacing between stirrup bars, respectively. It is suggested that the height and width should be $0.3-0.4$ times the length of the root and about 0.1 times the pile diameter, respectively. In addition, the height and width should be less than $400 \mathrm{~mm}$ and $300 \mathrm{~mm}$, respectively; if not, the height and width should be reduced by increasing reinforcement ratio or increasing concrete strength of roots. 


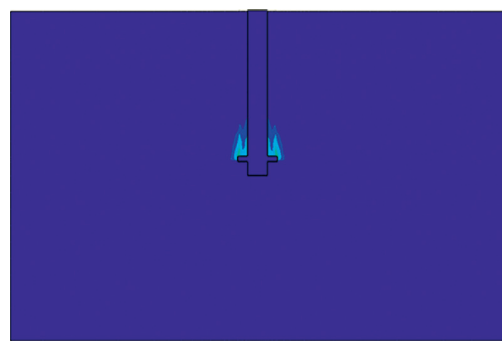

(a)

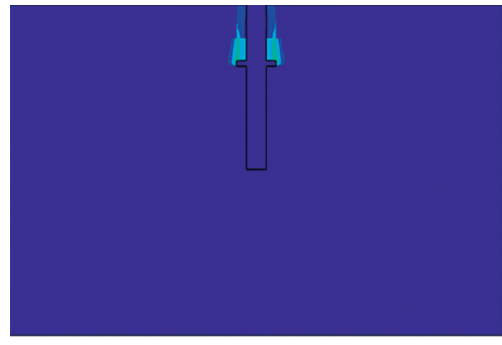

(d)

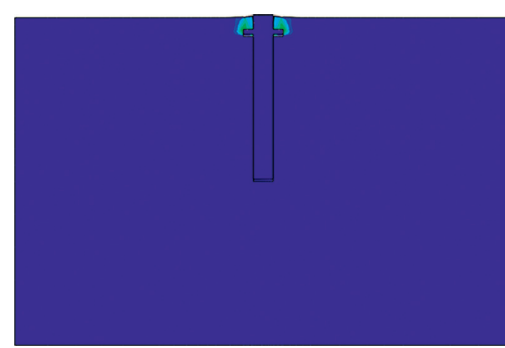

(b)

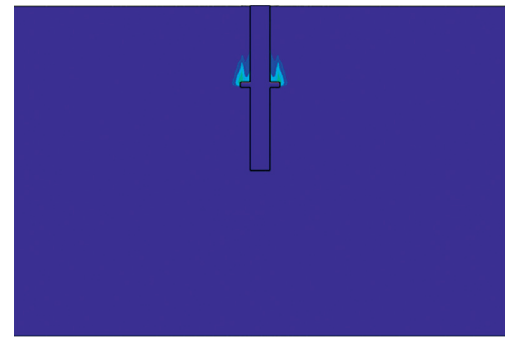

(e)

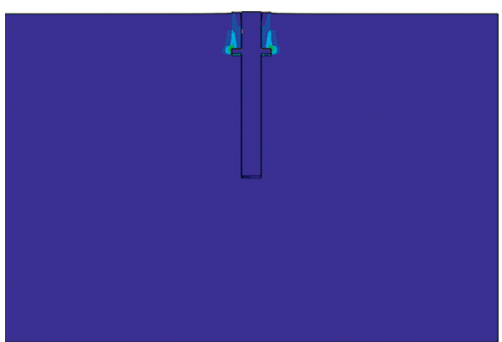

(c)

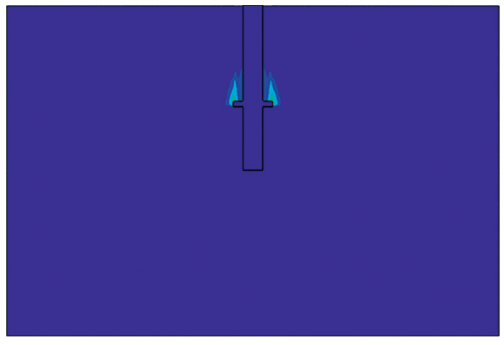

(f)

FIGURE 10: Plastic zone distribution of one root layer RP under ultimate bearing capacity. (a) RP No. 4. (b) RP No. 6. (c) RP No. 7. (d) RP No. 8. (e) RP No. 9. (f) RP No. 10.

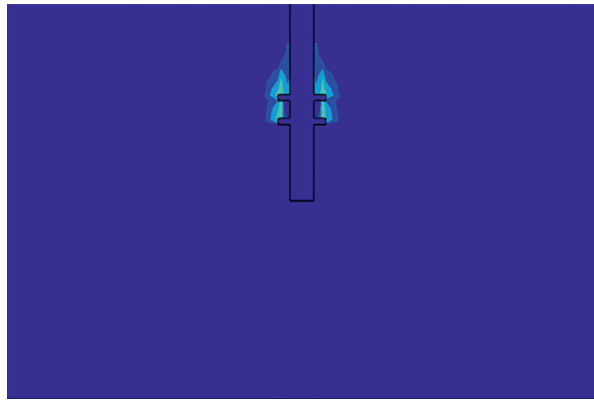

(a)

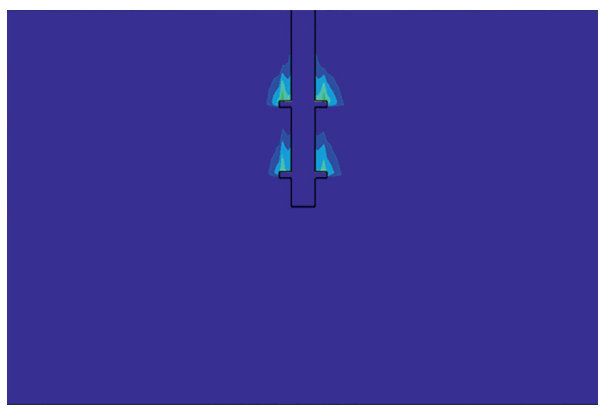

(c)

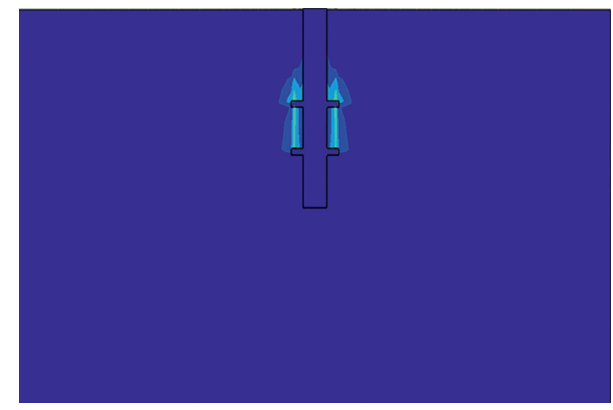

(b)

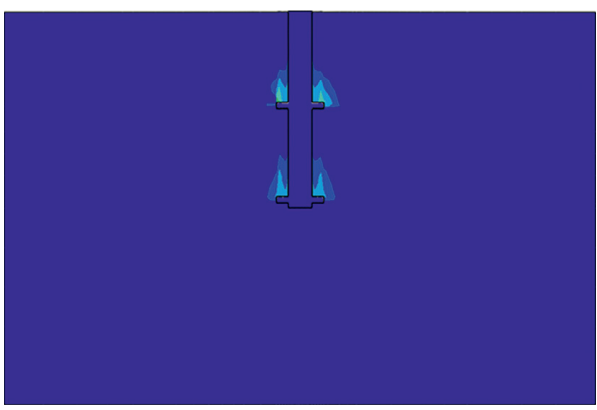

(d)

Figure 11: Plastic zone distribution of RP. (a) RP No. 11. (b) RP No. 12. (c) RP No. 13. (d) RP No. 14.

4.2.3. The Influence of Hollow Sections. In order to compare the influence of wall thickness and burial depth of hollow sections on the uplift bearing capacity of piles and to optimize the design of large-diameter piles, the simulation of hollow piles with different parameters was carried out. Specific simulation programs and the corresponding results are shown in Table 5, and the load displacement curves of the piles are shown in Figure 15. The chart indicates that the uplift bearing capacity was basically unaffected neither by wall thickness nor buried depth of hollow sections.

The arrangement of the hollow sections would change the stress distribution of piles. Because of the tension condition of piles and small tensile strength of concrete, it is necessary to compare the stress distribution of hollow piles. For piles with diameters $1.2,2.0$, and $2.8 \mathrm{~m}$, the axial stress 
TABLE 3: Simulation programs and results of piles with different length.

\begin{tabular}{|c|c|c|c|c|c|}
\hline $\begin{array}{l}\text { Pile } \\
\text { No. }\end{array}$ & $\begin{array}{l}\text { Length } \\
\text { (m) }\end{array}$ & $\begin{array}{l}\text { Pile } \\
\text { type }\end{array}$ & Buried depth of roots & $\begin{array}{l}\text { Ultimate bearing capacity } Q_{\mathrm{u}} \\
\qquad(\mathrm{kN})\end{array}$ & $\begin{array}{l}Q_{\mathrm{u}} \text { increment compared with the same length } \\
\text { SP (\%) }\end{array}$ \\
\hline 16 & \multirow{3}{*}{5} & & SP & \multicolumn{2}{|c|}{ Mutation, $16.70 \mathrm{~mm}, 700 \mathrm{kN}$} \\
\hline 17 & & & PP & 1490 & 112.9 \\
\hline 18 & & $\mathrm{RP}$ & $1 \mathrm{~d}, 3.5 \mathrm{~d}$ & 1596 & 128.0 \\
\hline 1 & \multirow{3}{*}{10} & & SP & \multicolumn{2}{|c|}{ Mutation, $2550 \mathrm{kN}, 32.13 \mathrm{~mm}$} \\
\hline 2 & & & $\mathrm{PP}$ & \multicolumn{2}{|c|}{59.7} \\
\hline 15 & & $\mathrm{RP}$ & $1 \mathrm{~d}, 4 \mathrm{~d}, 7 \mathrm{~d}$ & 4413 & 78.3 \\
\hline 19 & \multirow{3}{*}{15} & & $\mathrm{SP}$ & \multicolumn{2}{|c|}{ Mutation, $5030 \mathrm{kN}, 54.92 \mathrm{~mm}$} \\
\hline 20 & & & $\mathrm{PP}$ & 5887 & 17.0 \\
\hline 21 & & $\mathrm{RP}$ & $1 \mathrm{~d}, 4 \mathrm{~d}, 7 \mathrm{~d} 10 \mathrm{~d}$ & 7136 & 41.9 \\
\hline 22 & \multirow{6}{*}{20} & & SP & \multicolumn{2}{|c|}{ Mutation, $7500 \mathrm{kN}, 52.67 \mathrm{~mm}$} \\
\hline 23 & & & $\mathrm{PP}$ & 8134 & 8.5 \\
\hline 24 & & $\mathrm{RP}$ & $\begin{array}{c}1 \mathrm{~d}, 4 \mathrm{~d}, 7 \mathrm{~d}, 10 \mathrm{~d}, 13 \mathrm{~d} \\
16 \mathrm{~d}\end{array}$ & 10000 & 33.3 \\
\hline 25 & & $\mathrm{RP}$ & $1 \mathrm{~d}, 4 \mathrm{~d}, 7 \mathrm{~d}$ & 9010 & 20.1 \\
\hline 26 & & $\mathrm{RP}$ & $1 \mathrm{~d}, 4 \mathrm{~d}, 7 \mathrm{~d}, 10 \mathrm{~d}$ & 9044 & 20.6 \\
\hline 27 & & $\mathrm{RP}$ & $1 \mathrm{~d}, 4 \mathrm{~d}, 7 \mathrm{~d}, 10 \mathrm{~d}, 13 \mathrm{~d}$ & 9648 & 28.6 \\
\hline 28 & \multirow{3}{*}{25} & \multirow{3}{*}{$\mathrm{RP}$} & SP & \multicolumn{2}{|c|}{ Mutation, $9975 \mathrm{kN}, 56.37 \mathrm{~mm}$} \\
\hline 29 & & & \multirow{2}{*}{ 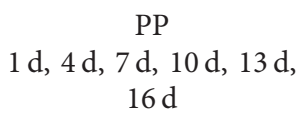 } & 10580 & 6.4 \\
\hline 30 & & & & 12114 & 21.4 \\
\hline
\end{tabular}

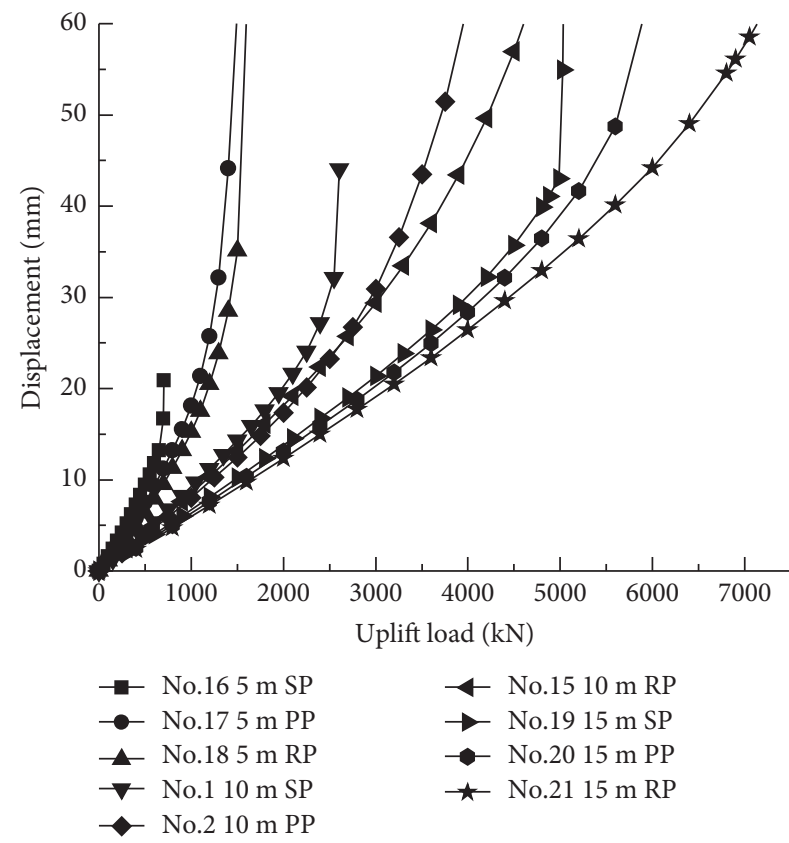

(a)

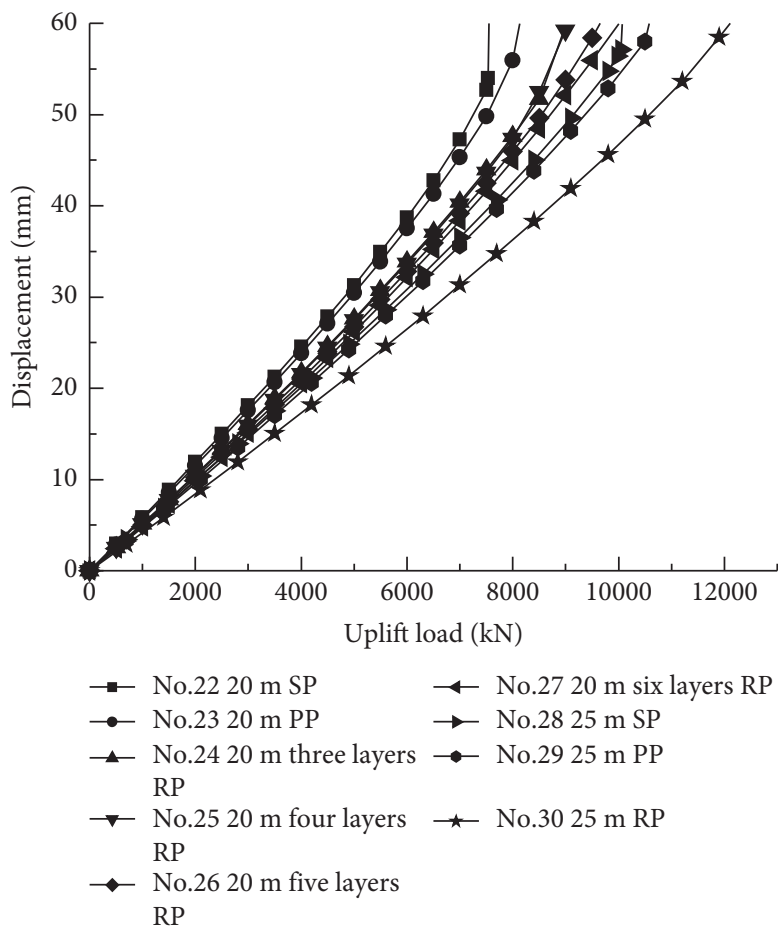

(b)

Figure 12: Uplift load displacement of piles with different length. (a) Pile length of 5, 10, and $15 \mathrm{~m}$. (b) Pile length of 20 and $25 \mathrm{~m}$.

distribution of the middle part of piles was extracted when the uplift load was 3000,5000 , and $6000 \mathrm{kN}$, respectively (the corresponding uplift displacement was all about $30 \mathrm{~mm}$ ), as shown in Figures 16-18. It should be noted that the elastic model was adopted for piles, and the cracking failure of piles was not considered.
Figures 16-18 indicate that the axial stress distribution of piles with a wall thickness of $0.5 \mathrm{~m}, 0.7 \mathrm{~m}$, and $0.9 \mathrm{~m}$ is similar to that of solid piles with diameters 1.2, 2.0, and $2.8 \mathrm{~m}$, respectively. Correspondingly, the ratio of wall thickness to pile diameter is $0.416,0.35$, and 0.32 , respectively. Furthermore, it could be inferred that for large- 
TABLE 4: Simulation programs and results of piles with different diameter.

\begin{tabular}{|c|c|c|c|c|c|c|c|}
\hline $\begin{array}{l}\text { Pile } \\
\text { No. }\end{array}$ & $\begin{array}{l}\text { Diameter } \\
(\mathrm{m})\end{array}$ & $\begin{array}{c}\text { Root size } \\
(\text { height } \times \text { width })\left(\mathrm{m}^{2}\right)\end{array}$ & $\begin{array}{c}\text { Root } \\
\text { length }(\mathrm{m})\end{array}$ & $\begin{array}{l}\text { Root No. } \\
\text { per layer }\end{array}$ & $\begin{array}{l}\text { Roots annular } \\
\text { spacing }(\mathrm{m})\end{array}$ & $\begin{array}{l}\text { Ultimate bearing } \\
\text { capacity } Q_{\mathrm{u}}(\mathrm{kN})\end{array}$ & $\begin{array}{c}Q_{\mathrm{u}} \text { increment compared } \\
\text { with the same diameter SP } \\
(\%)\end{array}$ \\
\hline 31 & \multirow{5}{*}{1.6} & \multirow{5}{*}{$0.3 \times 0.15$} & \multirow{5}{*}{0.8} & \multicolumn{2}{|r|}{ SP } & \\
\hline 32 & & & & \multicolumn{2}{|r|}{$\mathrm{PP}$} & \multicolumn{2}{|c|}{ 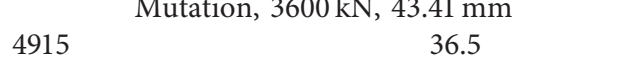 } \\
\hline 33 & & & & 6 & 0.687 & 5622 & 56.2 \\
\hline 34 & & & & 8 & 0.478 & 5947 & 65.2 \\
\hline 35 & & & & 10 & 0.352 & 6125 & 70.1 \\
\hline 36 & \multirow{7}{*}{2.0} & \multirow{7}{*}{$0.4 \times 0.2$} & & \multicolumn{2}{|r|}{ SP } & \multicolumn{2}{|c|}{ Mutation, $4650 \mathrm{kN}, 52.00 \mathrm{~mm}$} \\
\hline 37 & & & & \multicolumn{2}{|r|}{ PP } & 6151 & 32.3 \\
\hline 38 & & & 1.0 & 8 & 0.585 & 7233 & 55.5 \\
\hline 39 & & & & 10 & 0.428 & 7416 & 59.5 \\
\hline 40 & & & & 12 & 0.323 & 7531 & 62.0 \\
\hline 41 & & & 0.8 & \multirow{2}{*}{10} & \multirow{2}{*}{0.428} & 7019 & 50.9 \\
\hline 42 & & & 1.2 & & & 7828 & 68.3 \\
\hline 43 & \multirow{5}{*}{2.4} & \multirow{5}{*}{$0.4 \times 0.2$} & & \multicolumn{2}{|r|}{ SP } & 5692 & - - \\
\hline 44 & & & & \multicolumn{2}{|r|}{$\mathrm{PP}$} & 7079 & 24.4 \\
\hline 45 & & & 1.2 & 10 & 0.554 & 8515 & 49.6 \\
\hline 46 & & & & 12 & 0.428 & 8684 & 52.6 \\
\hline 47 & & & & 14 & 0.338 & 8809 & 54.8 \\
\hline 48 & \multirow{8}{*}{2.8} & \multirow{8}{*}{$0.4 \times 0.3$} & & \multirow{2}{*}{\multicolumn{2}{|c|}{$\begin{array}{l}\text { SP } \\
\text { PP }\end{array}$}} & 6608 & -- \\
\hline 49 & & & & & & 8505 & 28.7 \\
\hline 50 & & & 1.4 & 10 & 0.579 & 9805 & 48.4 \\
\hline 51 & & & & 12 & 0.433 & 9997 & 51.3 \\
\hline 52 & & & & 14 & 0.328 & 10154 & 53.7 \\
\hline 53 & & & 1.0 & & & 9158 & 38.6 \\
\hline 54 & & & 1.2 & 12 & 0.433 & 9600 & 45.3 \\
\hline 55 & & & 1.6 & & & 10378 & 57.7 \\
\hline
\end{tabular}

Note. The length of the piles above is $10 \mathrm{~m}$, and all of the RP were arranged as three root layers with buried depth at $1.2 \mathrm{~m}, 4.8 \mathrm{~m}$, and $8.4 \mathrm{~m}$, respectively.

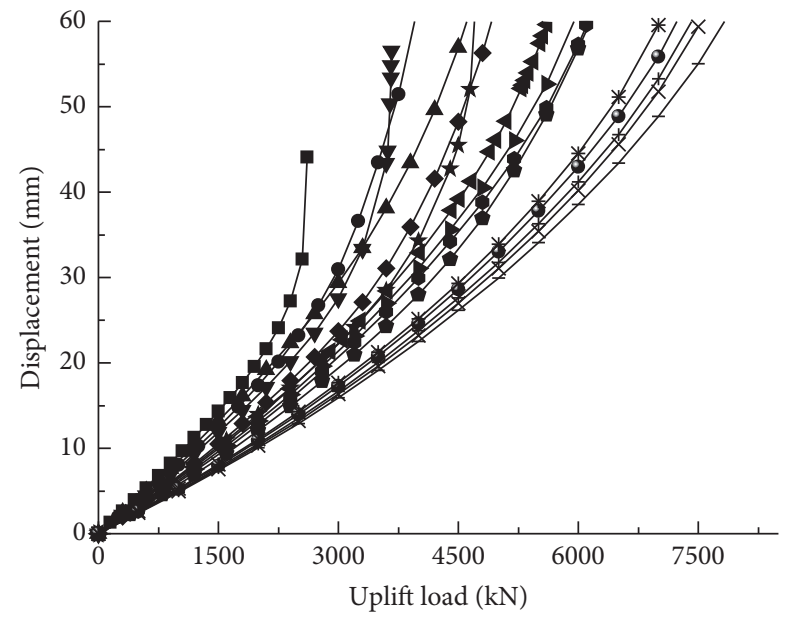

$\rightarrow$ No.1 $1.2 \mathrm{~m} \mathrm{SP}$

$\rightarrow$ No.2 $1.2 \mathrm{~m} \mathrm{PP}$

— No.15 $1.2 \mathrm{~m} \mathrm{RP}$

$\checkmark$ No.31 $1.6 \mathrm{~m} \mathrm{SP}$

$\multimap$ No.32 $1.6 \mathrm{mPP}$

$\longleftarrow$ No.33 1.6m RP with 6 roots per layer

$\rightarrow$ No.34 $1.6 \mathrm{~m} \mathrm{RP}$ with 8 roots per layer

$\rightarrow$ No.35 $1.6 \mathrm{~m}$ RP with 10 roots per layer

* No.36 $2.0 \mathrm{~m} \mathrm{SP}$

$\rightarrow$ No.37 $2.0 \mathrm{mPP}$

- No.38 $2.0 \mathrm{~m}$ RP with 8 roots per layer

+ No.39 2.0 m RP with 10 roots per layer

$\rightarrow$ No.40 2.0 m RP with 12 roots per layer

* No.41 $2.0 \mathrm{~m} \mathrm{RP}$, root length of $0.8 \mathrm{~m}$

_- No.42 2.0m RP, root length of $1.2 \mathrm{~m}$

(a)

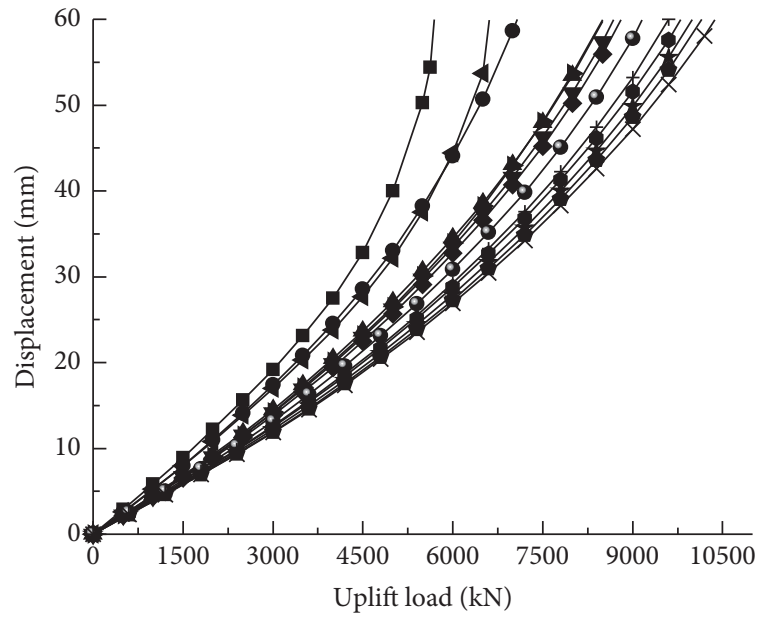

$\rightarrow$ No.43 $2.4 \mathrm{~m} \mathrm{SP}$

$\rightarrow$ No.44 $2.4 \mathrm{~m} \mathrm{PP}$

$\neg$ No.45 2.4m RP with 10 roots per layer

$\rightarrow \quad$ No.46 $2.4 \mathrm{~m} \mathrm{RP}$ with 12 roots per layer

- No.47 $2.4 \mathrm{~m} \mathrm{RP}$ with 14 roots per layer

$\longleftarrow$ No.48 $2.8 \mathrm{~m} \mathrm{SP}$

$\rightarrow$ No.49 $2.8 \mathrm{~m} \mathrm{PP}$

$\rightarrow-$ No.50 2.8m RP with 10 roots per layer

* No.51 $2.8 \mathrm{~m} \mathrm{RP}$ with 12 roots per layer

- No.52 $2.8 \mathrm{~m}$ RP with 14 roots per layer

$\rightarrow$ No.53 2.8m RP, root length of $1.0 \mathrm{~m}$

工 No.54 $2.8 \mathrm{~m} \mathrm{RP}$, root length of $1.2 \mathrm{~m}$

$\times$ No.55 $2.8 \mathrm{~m} \mathrm{RP}$, root length of $1.6 \mathrm{~m}$

FIGURe 13: : Uplift load displacement of piles with different diameter. (a) Pile diameter of 1.2, 1.6, and 2.0 m. (b) Pile diameter of 2.4 and $2.8 \mathrm{~m}$. 


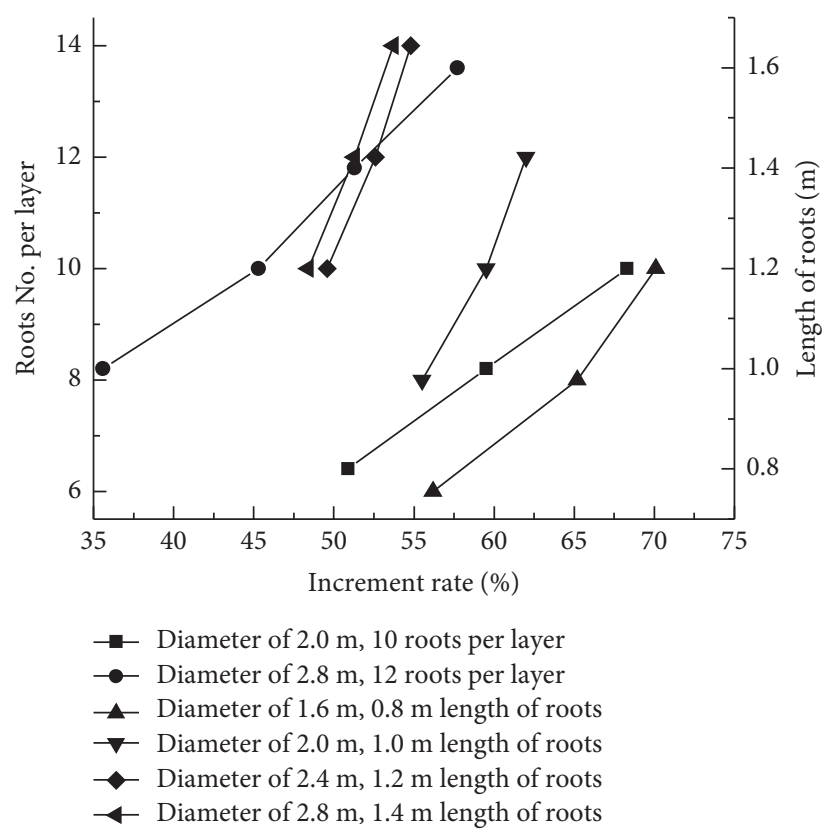

Figure 14: $Q_{\mathrm{u}}$ increment of RP with different number and length of roots.

TABLE 5: Simulation programs and results of hollow piles.

\begin{tabular}{|c|c|c|c|c|c|}
\hline $\begin{array}{l}\text { Pile } \\
\text { No. }\end{array}$ & $\begin{array}{l}\text { Diameter } \\
(\mathrm{m})\end{array}$ & $\begin{array}{c}\text { Wall } \\
\text { thickness (m) }\end{array}$ & $\begin{array}{l}\text { Buried depth of } \\
\text { hollow section }(\mathrm{m})\end{array}$ & $\begin{array}{l}\text { The bearing capacity corresponding } \\
\text { to } 30 \mathrm{~mm} \text { uplift displacement }(\mathrm{kN})\end{array}$ & $\begin{array}{l}\text { The bearing capacity corresponding } \\
\text { to } 60 \mathrm{~mm} \text { uplift displacement }(\mathrm{kN})\end{array}$ \\
\hline 15 & \multirow{6}{*}{1.2} & & Solid pile & 3118 & 4413 \\
\hline 56 & & 0.3 & \multirow{3}{*}{$\begin{array}{l}1.35-8.25 \text { (between } \\
\text { the } 1^{\text {st }} \text { and } 3^{\text {rd }} \text { layer) }\end{array}$} & 3079 & 4356 \\
\hline 57 & & 0.4 & & 3097 & 4381 \\
\hline 58 & & 0.5 & & 3107 & 4395 \\
\hline 59 & & 04 & $\begin{array}{l}1.35-4.65 \text { (between } \\
\text { the } 1^{\text {st }} \text { and } 2^{\text {nd }} \text { layer) }\end{array}$ & 3104 & 4392 \\
\hline 60 & & 0.4 & $\begin{array}{l}4.95-8.25 \text { (between } \\
\text { the } 2^{\text {nd }} \text { and } 3^{\text {rd }} \text { layer) }\end{array}$ & 3105 & 4391 \\
\hline 39 & \multirow{4}{*}{2.0} & & Solid pile & 4789 & 7416 \\
\hline 61 & & 0.4 & \multirow{3}{*}{$\begin{array}{l}1.35-8.25 \text { (between } \\
\text { the } 1^{\text {st }} \text { and } 3^{\text {rd }} \text { layer) }\end{array}$} & 4696 & 7253 \\
\hline 62 & & 0.55 & & 4817 & 7345 \\
\hline 63 & & 0.7 & & 4753 & 7342 \\
\hline 51 & \multirow{4}{*}{2.8} & & Solid pile & 6329 & 9997 \\
\hline 64 & & 0.5 & \multirow{3}{*}{$\begin{array}{l}1.35-8.25 \text { (between } \\
\text { the } 1^{\text {st }} \text { and } 3^{\text {rd }} \text { layer) }\end{array}$} & 6161 & 9712 \\
\hline 65 & & 0.7 & & 6266 & 9875 \\
\hline 66 & & 0.9 & & 6318 & 9945 \\
\hline
\end{tabular}

Note. The hollow sections of pile No. 56-60, 61-63, and 64-66 were arranged based on pile No. 15, 39, and 51, respectively. All of the piles were $10 \mathrm{~m}$ long and arranged as three root layers with buried depth at $1.2 \mathrm{~m}, 4.8 \mathrm{~m}$, and $8.4 \mathrm{~m}$, respectively.

diameter piles, hollow sections could be adopted to reduce material consumption. The wall thickness of hollow piles should be $0.3-0.4$ times the pile diameter, and the larger the pile diameter, the smaller the value. In addition, stress concentration would occur at roots and the joint between pile shaft and roots, and structural measures, such as increasing the concrete grade and reinforcement ratios, should be considered to get roots and the joint strengthened.

4.2.4. Discussion on the Influence of Pile Length and Diameter and Hollow Sections. The comparison of the influence of pile length and diameter on the bearing capacity of different pile types is shown in Figure 19, in which the number of root layers of $\mathrm{RP}$ length ranging from $5 \mathrm{~m}$ to $25 \mathrm{~m}$ is $2-6$, respectively, the length of the root is half of the pile diameter, and the annular spacing of roots is between 0.4 and $0.5 \mathrm{~m}$. As seen from Figure 19, the $Q_{\mathrm{u}}$ increment of PP and RP compared with SP remains basically unchanged with the increase in pile diameter, that is, the influence of pile diameter on bearing capacity of SP, $\mathrm{PP}$, and RP is similar. However, the influence of pile length on bearing capacity of different pile types shows different trends. Both PP and RP could be used to improve the pile uplift bearing capacity when the pile length is no more than $10 \mathrm{~m}$. For piles no less than $15 \mathrm{~m}$ long, compared with the increment of the bearing capacity of RP, the increment of PP is smaller. 


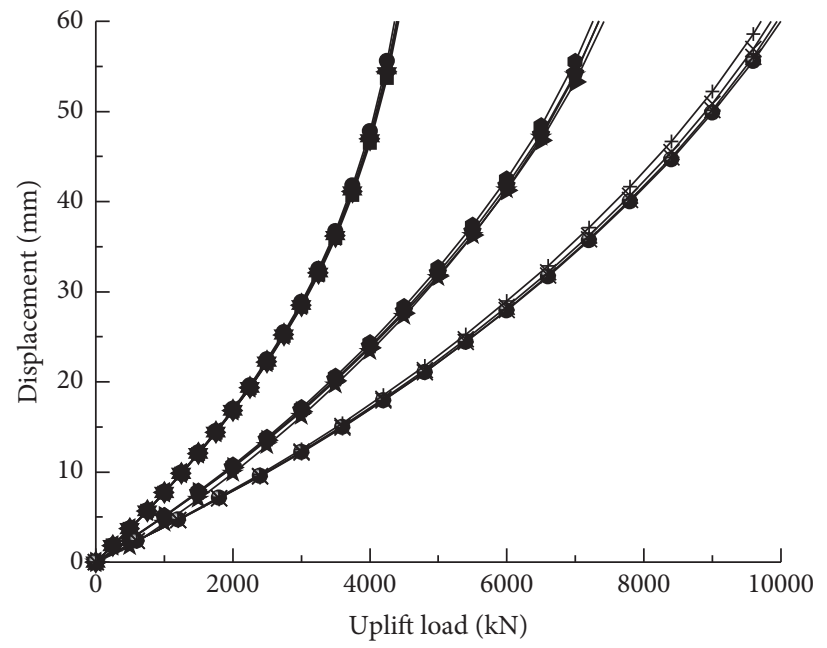

$\rightarrow$ No.15 solid pile and diameter of $1.2 \mathrm{~m}$

$\rightarrow$ No.56 diameter of $1.2 \mathrm{~m}$ and wall thickness of $0.3 \mathrm{~m}$

$\simeq$ No.57 diameter of $1.2 \mathrm{~m}$ and wall thickness of $0.4 \mathrm{~m}$

$\rightarrow$ No.58 diameter of $1.2 \mathrm{~m}$ and wall thickness of $0.5 \mathrm{~m}$

$\multimap$ No.59 diameter of $1.2 \mathrm{~m}$ and 1.35-4.65 m depth of hollow section

$\longleftarrow$ No.60 diameter of $1.2 \mathrm{~m}$ and 4.95-8.25 $\mathrm{m}$ depth of hollow section

$\rightarrow$ No.39 solid pile and diameter of $2.0 \mathrm{~m}$

$\rightarrow$ No.61 diameter of $2.0 \mathrm{~m}$ and wall thickness of $0.4 \mathrm{~m}$

* No.62 diameter of $2.0 \mathrm{~m}$ and wall thickness of $0.55 \mathrm{~m}$

$\rightarrow$ No.63 diameter of $2.0 \mathrm{~m}$ and wall thickness of $0.7 \mathrm{~m}$

$\rightarrow$ No.51 solid pile and diameter of $2.8 \mathrm{~m}$

$\rightarrow$ No.64 diameter of $2.8 \mathrm{~m}$ and wall thickness of $0.5 \mathrm{~m}$

$\rightarrow$ No.65 diameter of $2.8 \mathrm{~m}$ and wall thickness of $0.7 \mathrm{~m}$

* No.66 diameter of $2.8 \mathrm{~m}$ and wall thickness of $0.9 \mathrm{~m}$

Figure 15: Uplift load displacement of piles with hollow sections.

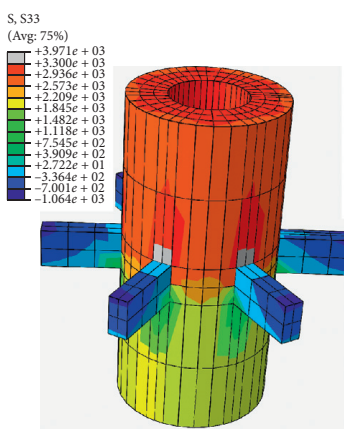

(a)

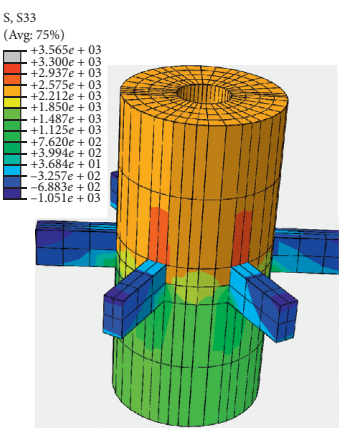

(b)

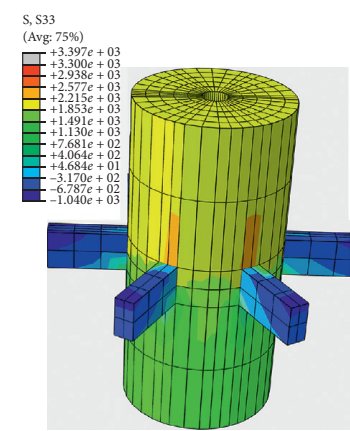

(c)

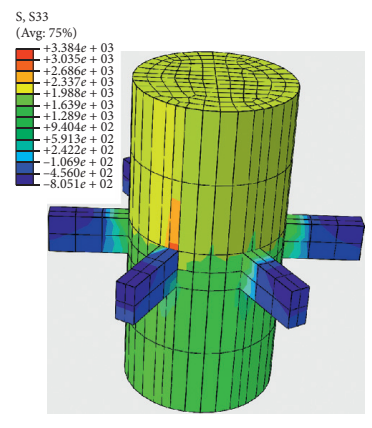

(d)

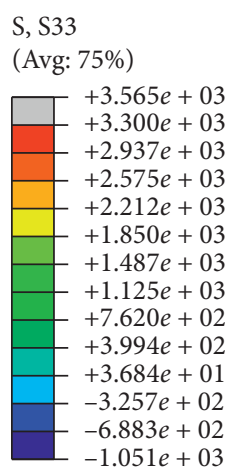

(e)

FIgURE 16: Axial stress distribution of piles of $1.2 \mathrm{~m}$ in diameter with different wall thickness. (a) $0.3 \mathrm{~m}$. (b) $0.4 \mathrm{~m}$. (c) $0.5 \mathrm{~m}$. (d) Solid pile. (e) The legend. The unit of the legend in Figures 16(e), 17(e), and 18(e) is $\mathrm{kPa}$.

The influence of pile length and diameter and hollow sections on the bearing capacity of per unit of concrete (hereafter called $Q_{\text {unit }}$ ) was compared with pile No. 15 (solid pile of $10 \mathrm{~m}$ in length and $1.2 \mathrm{~m}$ in diameter), and the results are shown in Table 6. The $Q_{\text {unit }}$ increment ratio tends to remain unchanged with the increase in pile length, while $Q_{\text {unit }}$ decreases with the increase in pile diameter, and the larger the pile diameter, the higher the reduction. In addition, within the scope of diameter of $2.8 \mathrm{~m}$, the arrangement of hollow sections has little influence on $Q_{\text {unit }}$. Taken together, improving pile bearing capacity through increasing pile length is more economical than through increasing pile diameter, but it must be pointed out that the construction process becomes harder with the increase of pile length. On 


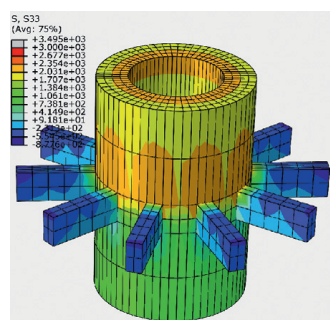

(a)

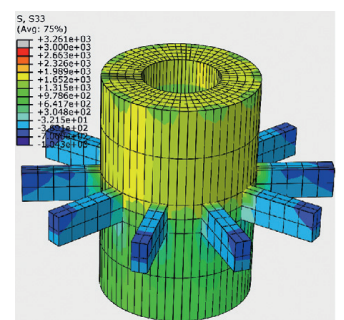

(b)

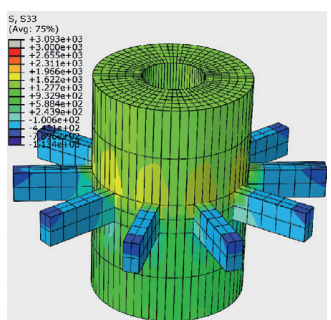

(c)

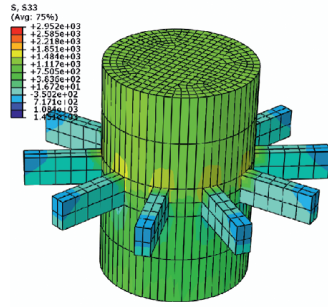

(d)

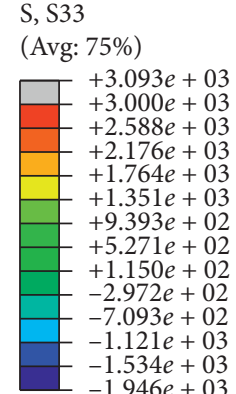

(e)

Figure 17: Axial stress distribution of piles of $2.0 \mathrm{~m}$ in diameter with different wall thickness. (a) $0.3 \mathrm{~m}$. (b) $0.55 \mathrm{~m}$. (c) $0.7 \mathrm{~m}$. (d) Solid pile. (e) The legend.

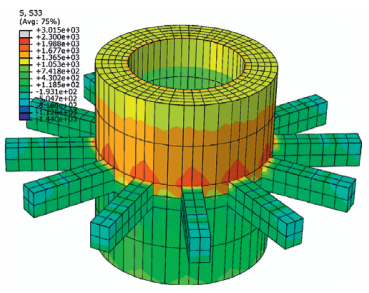

(a)

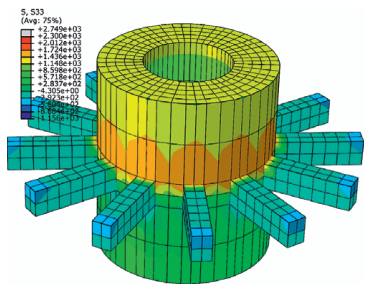

(b)

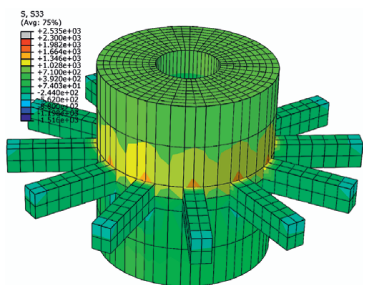

(c)

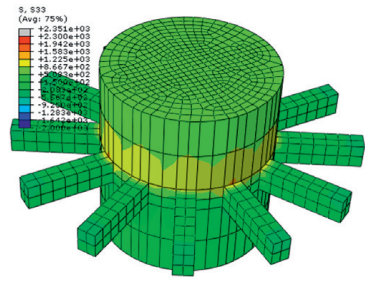

(d)

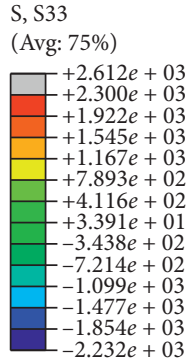

(e)

FIGURE 18: Axial stress distribution of piles of $2.8 \mathrm{~m}$ in diameter with different wall thickness. (a) $0.5 \mathrm{~m}$. (b) $0.7 \mathrm{~m}$. (c) $0.9 \mathrm{~m}$. (d) Solid pile. (e) The legend.

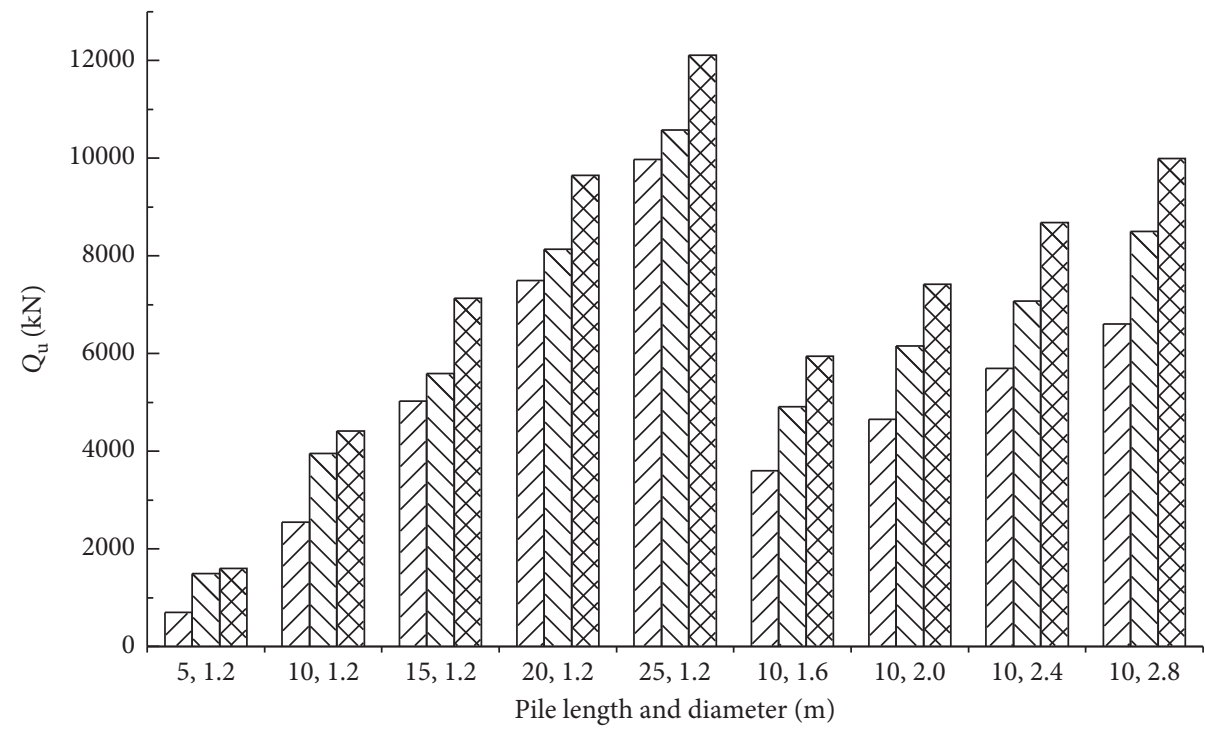

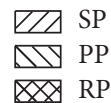

FIGURE 19: Ultimate bearing capacity of piles with different length and diameter.

the whole, the influence of construction difficulty and concrete consumption should be considered comprehensively.
In order to study the influence of buried depth of roots and pile diameter on the plastic zone above roots, the plastic zones of RP with diameters ranging from $1.2 \mathrm{~m}$ to $2.4 \mathrm{~m}$ and 
TABLE 6: The influence of pile length and diameter and hollow sections on the bearing capacity.

\begin{tabular}{|c|c|c|c|c|c|c|}
\hline $\begin{array}{l}\text { Pile } \\
\text { No. }\end{array}$ & $\begin{array}{l}\text { Length } \\
(\mathrm{m})\end{array}$ & $\begin{array}{l}\text { Diameter } \\
(\mathrm{m})\end{array}$ & $\begin{array}{c}\text { Concrete } \\
\text { consumption }\left(\mathrm{m}^{3}\right)\end{array}$ & $\begin{array}{l}\text { Ultimate bearing } \\
\text { capacity } Q_{\mathrm{u}}(\mathrm{kN})\end{array}$ & $\begin{array}{l}\text { Bearing capacity per unit of } \\
\text { concrete } Q_{\text {unit }}\left(\mathrm{kN} / \mathrm{m}^{3}\right)\end{array}$ & $\begin{array}{c}Q_{\text {unit }} \text { increment compared } \\
\text { with pile No. } 15(\%)\end{array}$ \\
\hline 15 & 10 & \multirow{4}{*}{1.2} & 11.79 & 4413 & 374.30 & - \\
\hline 21 & 15 & & 17.60 & 7136 & 405.36 & 8.30 \\
\hline 27 & 20 & & 23.42 & 9648 & 411.99 & 10.07 \\
\hline 30 & 25 & & 29.23 & 12114 & 414.41 & 10.72 \\
\hline 34 & \multirow{7}{*}{10} & 1.6 & 20.96 & 5947 & 283.73 & -24.20 \\
\hline 39 & & 2.0 & 33.80 & 7416 & 219.41 & -41.38 \\
\hline 46 & & 2.4 & 48.67 & 8684 & 178.42 & -52.33 \\
\hline 51 & & 2.8 & 67.59 & 9997 & 147.90 & -60.49 \\
\hline 58 & & 1.2 & 11.30 & 4395 & 388.80 & 3.87 \\
\hline 63 & & 2.0 & 30.33 & 7342 & 242.07 & -35.33 \\
\hline 66 & & 2.8 & 62.17 & 9945 & 159.97 & -57.26 \\
\hline
\end{tabular}

Note. Pile No. 58, 63, and 66 are hollow piles.

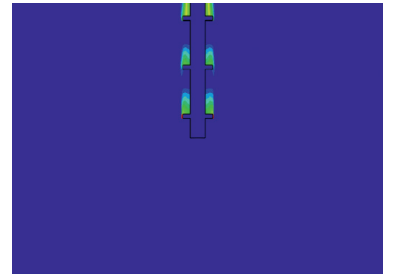

(a)

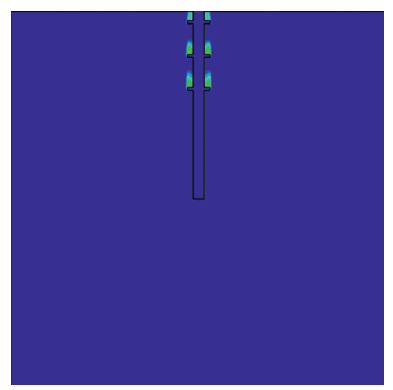

(e)

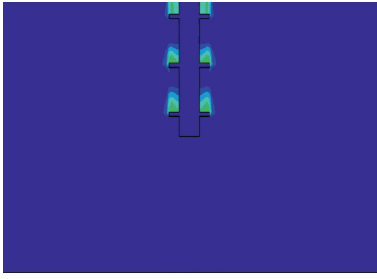

(b)

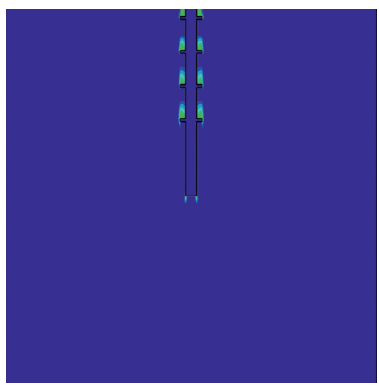

(f)

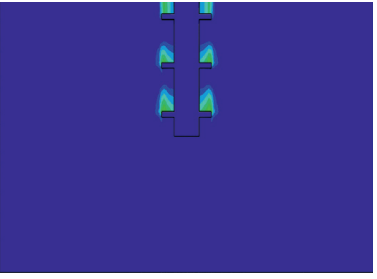

(c)

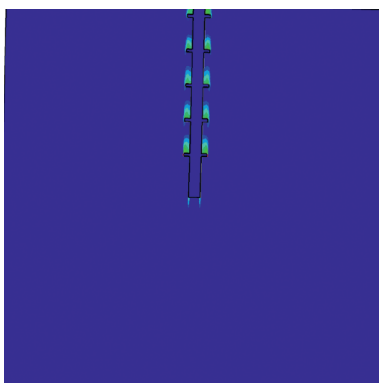

(g)

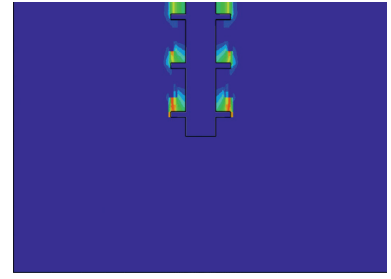

(d)

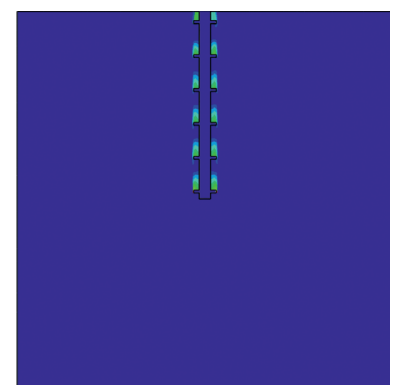

(h)

Figure 20: Plastic zone of RP with different buried depth of roots and pile diameter. (a) Diameter of $1.2 \mathrm{~m}$. (b) Diameter of $1.6 \mathrm{~m}$. (c) Diameter of $2.0 \mathrm{~m}$. (d) Diameter of $2.4 \mathrm{~m}$. (e) RP of three layers. (f) RP of four layers. (g) RP of five layers. (h) RP of six layers.

$\mathrm{RP}$ of $20 \mathrm{~m}$ in length with different number of root layers were extracted under $Q_{\mathrm{u}}$, as shown in Figure 20. The range of the plastic zone, which were all concentrated in the range of about $2.4 \mathrm{~m}$ above the roots, remained basically unchanged with the increase in root depth and pile diameter. In other words, the spacing of root layers is independent of pile length and diameter and should not be less than $2.4 \mathrm{~m}$.

\section{Conclusions}

In this paper, the finite element models of RP under uplift load were established, and the influence of root arrangement and pile diameter and length on bearing capacity of piles was studied. The following conclusions are obtained:

(1) The bearing capacity of piles could be greatly improved by arranging roots on the pile shaft, and the uplift bearing capacity of RP increases with the increase in pile length and diameter, root length and number, and number of root layers. In addition, the bearing capacity was basically unaffected by the arrangement of hollow sections.

(2) Both PP and RP could be used to improve the pile uplift bearing capacity when the pile length is no more than $10 \mathrm{~m}$. For piles no less than $15 \mathrm{~m}$, the advantages of RP in bearing capacity and construction feasibility are more obvious than those of $\mathrm{PP}$, and it is more convenient to use RP to improve the bearing capacity. The more the number of root layers, the higher the uplift bearing capacity, while the effect of the root arranged on the lower part of the pile on the resistance of the uplift load is small, and the number of root layers should not be too much. In addition, the spacing of root layers is independent of pile length and diameter and should not be less than $2.4 \mathrm{~m}$.

(3) Improving pile bearing capacity through increasing pile length is more economical than through increasing pile diameter, but it must be pointed out 
that the construction process becomes harder with the increase in pile length. In addition, the effect of hollow sections on reducing concrete consumption is not obvious for large-diameter piles. On the whole, the influence of construction difficulty and concrete consumption should be considered comprehensively.

(4) Bearing mechanism of the root is similar to the cantilever beam under uniform load. The influence of root length on the bearing capacity is greater than the root number. It is suggested that the length of the root should not exceed 0.5 times the pile diameter and the number of roots should correspond with the root annular spacing of $0.4-0.5 \mathrm{~m}$. In addition, it is suggested that the height and width of the root should be 0.3-0.4 times the length of the root and about 0.1 times the pile diameter, respectively, and should not affect the reinforcement.

\section{Data Availability}

The data used to support the findings of this study are available from the corresponding author upon request.

\section{Conflicts of Interest}

The authors declare that there are no conflicts of interest regarding the publication of this paper.

\section{Acknowledgments}

This work was supported by the Graduate Research and Innovation Foundation of Chongqing, China (No. CYB18126) and the Science and Technology Project of Northwest Electric Power Design Institute Co., Ltd. (No. XB1-TM05-2017).

\section{References}

[1] D. L. Qian, "Engineering application study of squeezed branch pile with high antipulling behavior (in Chinese)," Chinese Journal of Rock Mechanics and Engineering, vol. 22, no. 4, pp. 678-682, 2003.

[2] M. Zhang, P. Xu, W. Cui, and Y. Gao, "Bearing behavior and failure mechanism of squeezed branch piles," Journal of Rock Mechanics and Geotechnical Engineering, vol. 10, no. 5, pp. 935-946, 2018.

[3] E. A. Dickin and C. F. Leung, "Performance of piles with enlarged bases subject to uplift forces," Canadian Geotechnical Journal, vol. 27, no. 5, pp. 546-556, 1990.

[4] K. Ilamparuthi and E. A. Dickin, "The influence of soil reinforcement on the uplift behaviour of belled piles embedded in sand," Geotextiles and Geomembranes, vol. 19, no. 1, pp. 1-22, 2001.

[5] A. K. Bera and U. Banerjee, "Uplift capacity of model bell shaped anchor embedded in sand," International Journal of Geotechnical Engineering, vol. 7, no. 1, pp. 84-90, 2013.

[6] G. Gao, M. Gao, Q. Chen, and J. Yang, "Field load testing study of vertical bearing behavior of a large diameter belled cast-in-place pile," KSCE Journal of Civil Engineering, vol. 23, no. 5, pp. 2009-2016, 2019.
[7] S. N. Rao, Y. V. S. N. Prasad, and M. D. Shetty, "The behaviour of model screw piles in cohesive soils," Soils and Foundations, vol. 31, no. 2, pp. 35-50, 1991.

[8] Z. H. Elsherbiny and M. H. El Naggar, "Axial compressive capacity of helical piles from field tests and numerical study," Canadian Geotechnical Journal, vol. 50, no. 12, pp. 1191-1203, 2013.

[9] Y. R. Lv, H. L. Liu, X. M. Ding, and G. K. Kong, "Field tests on bearing characteristics of X-section pile composite foundation," Journal of Performance of Constructed Facilities, vol. 26, no. 2, pp. 180-189, 2011.

[10] H. Zhou, H. Liu, J. Yuan, and J. Chu, "Numerical simulation of XCC pile penetration in undrained clay," Computers and Geotechnics, vol. 106, pp. 18-41, 2019.

[11] Y. G. Yin, "Scheme conception of root foundation and anchor block," Highway, vol. 51, no. 2, pp. 46-49, 2007, in Chinese.

[12] W. M. Gong, F. Hu, X. D. Tong, and Y. G. Yin, "Experimental study on vertical bearing capacity of root foundation," Chinese Journal of Geotechnical Engineering, vol. 30, no. 12, pp. 1789-1795, 2008, in Chinese.

[13] Y. G. Yin, D. H. Sun, and W. M. Gong, "Experiment and numerical simulation of the bearing characteristics of root foundations," China Civil Engineering Journal, vol. 42, no. 12, pp. 162-169, 2009, in Chinese.

[14] S. Y. Lam, C. W. W. Ng, C. F. Leung, and S. H. Chan, "Centrifuge and numerical modeling of axial load effects on piles in consolidating ground," Canadian Geotechnical Journal, vol. 46, no. 1, pp. 10-24, 2009.

[15] C. W. W. Ng, H. G. Poulos, V. S. H. Chan, S. S. Y. Lam, and G. C. Y. Chan, "Effects of tip location and shielding on piles in consolidating ground," Journal of Geotechnical and Geoenvironmental Engineering, vol. 134, no. 9, pp. 1245-1260, 2008.

[16] F. H. Kulhawy, J. L. Withiam, and D. W. Kozera, "Uplift testing of model drilled shafts in sand," Journal of the Geotechnical Engineering Division, vol. 105, no. 1, pp. 31-47, 1979.

[17] J. Xu, J. Ren, Z. Wang, S. Wang, and J. Yuan, "Strength behaviors and meso-structural characters of loess after freezethaw," Cold Regions Science and Technology, vol. 148, pp. 104-120, 2018.

[18] J. Xu, Y. Li, W. Lan, and S. Wang, "Shear strength and damage mechanism of saline intact loess after freeze-thaw cycling," Cold Regions Science and Technology, vol. 164, Article ID 102779, 2019. 